Florida International University FIU Digital Commons

\title{
Depictions of Fear in Lev Tolstoy's Sevastopol Sketches and Stephen Crane's The Red Badge of Courage
}

\author{
Ralph Willard Schusler Jr \\ Florida International University, rschus01@fiu.edu
}

DOI: $10.25148 /$ etd.FIDC001795

Follow this and additional works at: https:// digitalcommons.fiu.edu/etd

Part of the American Literature Commons, Comparative Literature Commons, History Commons, Modern Literature Commons, and the Russian Literature Commons

\section{Recommended Citation}

Schusler, Ralph Willard Jr, "Depictions of Fear in Lev Tolstoy's Sevastopol Sketches and Stephen Crane's The Red Badge of Courage" (2017). FIU Electronic Theses and Dissertations. 3180.

https://digitalcommons.fiu.edu/etd/3180 


\section{FLORIDA INTERNATIONAL UNIVERSITY}

Miami, Florida

\section{DEPICTIONS OF FEAR IN LEV TOLSTOY'S SEVASTOPOL SKETCHES} AND STEPHEN CRANE'S THE RED BADGE OF COURAGE

A thesis submitted in partial fulfillment of the

requirements for the degree of

MASTER OF ARTS

in

ENGLISH

by

Ralph W. Schusler Jr. 


\section{To: Dean Michael R. Heithaus}

College of Arts, Sciences and Education

This thesis, written by Ralph Schusler Jr., and entitled Depictions of Fear in Lev Tolstoy's Sevastopol Sketches and Stephen Crane's The Red Badge of Courage, having been approved in respect to style and intellectual content, is referred to you for judgement.

We have read this thesis and recommend that it be approved.

$\begin{array}{r}\hline \text { Nathaniel Cadle } \\ \hline \text { Michael Gillespie } \\ \hline \text { Bruce Harvey, Major Professor }\end{array}$

Date of Defense: March 29, 2017

The thesis of Ralph W. Schusler Jr. is approved.

Dean Michael R. Heithaus

College of Arts, Sciences and Education

Andrés G. Gil

Vice President for Research and Economic Development and Dean of the University Graduate School

Florida International University, 2017 


\section{DEDICATION}

I dedicate this thesis to the memory of my late parents, Ralph and Marjorie

Schusler; John and Lucy Jinishian; my brother, George; and my daughter, Stefanny.

"We do not fear being called meticulous, inclining as we do to the view that only the exhaustive can be truly interesting."

- Thomas Mann, "The Magic Mountain” 


\section{ACKNOWLEDGMENTS}

I wish to thank the members of my committee for their continuing encouragement and support. Dr. Nathaniel Cadle fired my interest in late $19^{\text {th }}$-century American literature and proved a steady boon, while Dr. Michael Gillespie opened my eyes to modernist writing and convinced me I could battle through a thesis. My major professor, Dr. Bruce Harvey, has proved an untiring and long-term ally in this effort, which has ranged from a first fruitless attempt to the culmination of this far-more-challenging project.

I would also like to thank the English Department of Florida International University - especially Drs. Jaime Sutton, Asher Milbauer and Kimberly Harrison - for enabling me to pursue this project as part of a highly collegial fellowship program that expanded my literary and professional horizons as greatly as I expanded the time limits for finishing a master's thesis.

Finally, I wish to thank Marlene Batista and Natasha Neckles for their timely help and cordial treatment; Dean Maureen Donnelly for her guidance and flexibility; Dean Donnelly's secretary, Mery Castro, for her encouragement; and ETD Coordinator Brandie Thomas for assuring passage through the final gate. 


\title{
ABSTRACT OF THE THESIS \\ DEPICTIONS OF FEAR IN LEV TOLSTOY'S SEVASTOPOL SKETCHES \\ AND STEPHEN CRANE'S THE RED BADGE OF COURAGE
}

\author{
by \\ Ralph W. Schusler Jr. \\ Florida International University, 2017 \\ Miami, Florida \\ Professor Bruce Harvey, Major Professor
}

The purpose of this thesis was to examine and compare two iconoclastic works dealing with war as experienced by combatants. So much of modern war fiction takes this perspective that one is hard pressed to imagine a time when such was not the case; the watershed was marked in the abovenamed works by the aforementioned writers, which, and who, were first in putting readers inside the heads of common soldiers facing mortal danger. These pioneering authors opened the door to modernist writing about boundary situations involving existential threat, as well as the psychological reactions they evoke especially fear. Depicting the toll the horrors of war take on individuals has helped humanize its study and enhanced our understanding of what had been a hidden cost of modern armed conflict. 
TABLE OF CONTENTS

$\begin{array}{ll}\text { CHAPTER } & \text { PAGE }\end{array}$

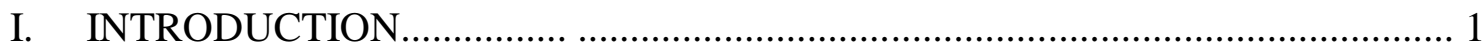

II. THE LAST DEGREE OF OTHERNESS: LIFE AND DEATH ON THE

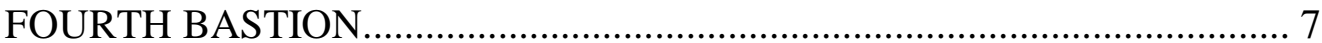

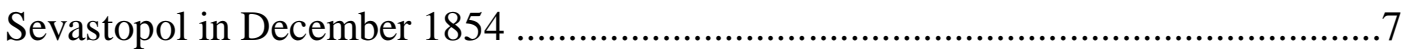

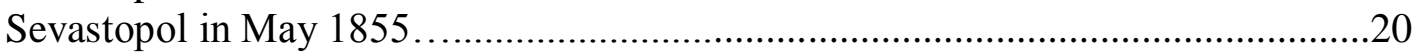

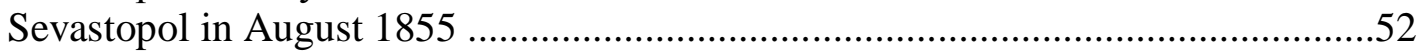

III. FROM A FOURTH BASTION OF HIS OWN INVENTION TO

THE RED BADGE OF COURAGE..................................................................77 


\section{CHAPTER I}

\section{INTRODUCTION}

Just as I cannot imagine a plesiosaurus on Nevsky Prospekt, I cannot imagine that anyone does not know what fear is and how it affects the organism.

- A. [M.] Dmitroevskii, editor of Военный сборник (War Collection), 1913 (Plamper 259).

Stephan Crane is famous for having never witnessed combat before writing the seminal American war novel, The Red Badge of Courage, which depicts the psychodrama besetting a youth before, during and after his first taste of fire. Crane's imaginative power and singular style distinguish his achievement, giving readers ringside seats inside Henry Fleming's head as his mind grapples with a premonition that grows into a force he cannot control until it shames him into becoming a man with a grip on his feelings. The work is commonly ranked among America's foremost Bildungsromanen, or coming-of-age novels, and stands as a hallmark of modernism, since the protagonist's thoughts, flowing between reality's banks, serve as the narrative current. With this work, Crane gave the war novel its classic form (Solomon 67).

The force Fleming fails to control is fear, a feature many readers find pervasive in Crane's writing, at large, and in The Red Badge, in particular. In an introduction to an edition published 102 years after the novel first appeared, former U.S. Poet Laureate James Dickey turned the primeval emotion into a predicate nominative for the writer:

Crane is fear, and that seems to me the case. Crane's glancing or peeking viewpoint is that of a person forced to look at an event or person, all the time wishing to avoid it, to turn his head, close his eyes, escape, go to sleep or die. The witnessed or imagined event is of such fascination, though, that the beholder 
cannot turn away, and endures as if in the worst possible nightmares. This is exactly the state of mind of a combatant soldier, as it is that of a poet who writes of horrors, helpless with fear and taking refuge in the only attitude possible: irony, a kind of induced superiority or indifference to the situation. (vi) Regarding that most primitive and powerful emotion in The Red Badge, none can better testify to its serving as lynchpin to the work than the author, himself, in words he penned, some three years post-publication, at the start of a letter to John Northern Hilliard, literary editor of the Rochester Post Express and a former fellow reporter in New York City in the early 1890's:

I have only one pride - and may it be forgiven me. This single pride is that the English edition of 'The Red Badge' has been received with praise by the English reviewers. Mr. George Wyndham, Under Secretary of War in the British Government, says, in an essay, that the book challenges comparison with the most vivid scenes of Tolstoi's War and Peace or of Zola's Downfall, and the big reviews praise it for just what I intended it to be, a psychological portrayal of fear." (Hilliard 72-73)

This riveting, cinematic account of war as witnessed from within a young man's highly impressionable, and sometimes hallucinatory, mind became an American literary landmark, which, in the words of noted curmudgeon H.L. Mencken, appeared "like a flash of lightening out of a clear winter sky; it was at once unprecedented and irresistible" (Sorrentino 172). Remarking on its fusion of four literary styles emerging at the time, Edwin H. Cady praised the work's "inviolably organic uniqueness. . . . There is no previous fiction like it" (Poetry Foundation). 
Subsequent war novels "like it” would abound, German critic Hans-Jörst Gierigk notes. The protagonists of time-honored works by such American literary giants as Ernest Hemingway, John Dos Passos and Norman Mailer follow closely in Henry Fleming's footsteps, and both Hemingway and William Faulkner praised the book as the only "real literature of our Civil War" and "the only good war story I know," respectively (Sorrentino 172).

The towering heights Crane achieved, however, owe much to the shoulders on which he stood: those of a Russian half a world away, an artillery officer whose service on the receiving end of a relentless French bombardment offered a window onto modernized warfare in all its horror. Lev Tolstoy required little of Crane's creativity upon composing his three-part Sevastopol Sketches, which covered the grim final stages of the Crimean War, "the first full conflagration of modernity, a global industrialized struggle fought with unusual ferocity and incompetence" (Paulsen). His unflinching firstperson accounts of the grisly scenes around him and dynamic psychological portraits of soldiers continuously subject to life-threatening menace proved "crucial ... [in] widening the boundaries of what soldiers could publically say about fear," Jan Plamper notes in his historical analysis of Russian military psychology; "Tolstoi sets his readers on a long road to fear, the central emotion in these stories, suggesting that one of his aims was to elicit fear in his readers" (263).

Gierigk might contend Plamper's conclusion regarding Tolstoy's intentions, while conceding the primacy of fear in his sketches: "Sevastopol provides a panorama of horrors that all the English penny dreadfuls combined can't approach. Tolstoy's poetic, however, is totally different from that of the penny dreadfuls, because here the horror 
resides not in the human soul but in the outer world" (245).Citing the closing sentence of "Sevastopol in May," probably the line most quoted of the trilogy's 120-plus pages, Gierigk takes the Russian realist at his word when he says," The hero of my tale - whom I love with all the power of my soul, and whom I have endeavored to portray in all his beauty, and who always has been, and ever will be, beautiful - is Truth (137). The horrors he depicts, in other words, are those he witnessed, while the fear was that which sundered the souls of both his comrades and Tolstoy, himself, who, along with Times of London's William Howard Russell, is considered the first war correspondent; Tolstoy, additionally, holds the singular distinction of being the world's first embedded war correspondent - albeit not from the Ernie Pyle school, as a civilian "typewriter soldier" for a major newspaper chain; nor the "Shock-and-Awe" school of civilian broadcasters traveling among invading troops, but, rather, by virtue of being an observant writer laboring as an artillery officer in a gruesome, merciless lost cause - and with a respected publication thirsting for his words. Plamper considers Tolstoy's vivid, graphic descriptions of the effect modern warfare works on human beings as the second most important of six factors that led to "widening the boundaries of what [Russian] soldiers could publically say about fear" (263). His work was bound to strike a chord in an aspiring author of Crane's lineage, who, himself, it might be said, was "looking for a fight." Given the justification he voiced after downing his first glass of beer at age six “How was I going to know what it tasted like less'n I tasted it? How you going to know about things at all less'n you do 'em?”- Crane's subsequent service as a war correspondent in two international conflicts must have owed in large measure to his hankering to know the real thing about which he had already heard, read, and written so 
much (Sorrentino 34). After his first taste of combat in the Greco-Turkish War, Crane paid himself modest tribute upon confirming to Joseph Conrad that, based on personal experience, "The Red Badge was all right" (Sorrentino 245). The carriage came before the horse with Crane - not with Tolstoy.

This thesis will examine the depiction of fear and the role it plays in the cited works of these two writers, attempting to clarify both the tribute Crane owed Tolstoy (and both owed Stendhal), as well as the ways in which Crane built upon Tolstoy's work to create a novel so singular that it helped usher in an altogether new approach to storytelling: modernism. To be covered are such topics as the danger of pre-battle bravado and the Dionysian mindset during conflict, engendered by what Gerigk, citing Friedrich Nietzsche, "calls "the aesthetic condition" (ästhetischer Zustand); the clutches of fear and freeing oneself from those clutches; and the aftermath of fear: loss of face, self-loathing and the need for, and means of, rectification. A final thread that touches on fear is the Christian ethos both writers weave throughout their works - Tolstoy in polemical broadsides condemning war, and Crane through subtler, situational devices that evince his upbringing as a preacher's son. Of consummate importance as the means by which these themes and feelings are portrayed are the two writers' innovative narrative techniques, in Tolstoy's case, described by N. G. Chernyshevsky as "interior monologue" and "the dialectic of the soul," and, in Crane's, as described by the author, himself, as the “cylinder of vision" (Holton, epigram).

The oddity of Crane's portraying action in a theater he'd never entered - that of war - has astounded critics and readers, alike, for more than a century, so the road that led to his assuming that challenge merits attention, especially in light of the fork in that 
road represented by Tolstoy; this thesis will trace that journey, as well as Tolstoy's more direct path to Sevastopol. The uncanny kinship of vision the two writers share becomes especially apparent upon exploring how each author treats the topic of this thesis: fear. 


\section{CHAPTER II}

\section{“THE LAST DEGREE OF OTHERNESS":}

\section{LIFE AND DEATH ON THE FOURTH BASTION}

Средь груды тлеюших костей, кто ирарь, кто раб, судья или воин? [Amid the heap of rotting bones, who is Tsar, who is slave, who is judge or warrior?]

\section{- $\quad$ Alexey Tolstoi, John Damascene}

(Wilson 99).

The Crimea was the first major war to be recorded by the camera. . . . At Sevastopol, more remarkably, there was a camera with intelligence called Tolstoy. His incomparable Sevastopol Sketches are cinéma verité of the very highest quality.

- A.N. Wilson (114)

At first he was terrified, then he mastered his quaking limbs and, from extreme fright, passed to extreme bravery; he did not know that the secret of his genius lay in just this rare capacity to shift from cowardice to heroism, or that it was his very flaws and inconsistencies that would later enable him to embrace the attitudes of each of his characters in turn with equal sincerity, or that his diversity as a man would be the foundation for his universality as a writer.

- Henri Troyat on Tolstoy at the Fourth Bastion (120-21)

It is no overstatement to say that no one who writes about men at war after Tolstoy does so without knowing what Tolstoy wrote about war. And this applies to not only American authors.

- Horst Jürgen Gierigk (33)

\section{Sevastopol in December 1854}

Benign Mother Nature in the form of dawn breaking above the Sapoune Hills and "throw [ing] off the gloom of night [on the] dark blue surface of the [Black S]ea" offers a 
serene prelude to the first of Leo Tolstoy's Sevastopol Sketches, but that opening paragraph barely concludes before a "reverberating boom " announces that readers will shortly be looking down the bore of cannon and musket (81). This juxtaposition of nature at peace and men at war becomes a leitmotif throughout the three sketches Tolstoy wrote about the siege of Sevastopol between December 1854 and September 1855. If, as Martine de Courcel noted, "For Tolstoy, the contemplation of nature would always be one of the paths to God," the contemplation of man at war would always be one of the paths in another direction (31). This becomes quickly evident in the first sketch, as the narrator, destroying the canon of war fiction and its focus on glorious feats and heroic deeds, leads the reader into and out of a makeshift operating theater:

The assistant surgeon throws the arm into a corner, while another wounded man on a stretcher who sees the operation turns and groans, more on account of the mental torture than from the physical pain he feels. You will witness these horrible, heart-rending scenes; you will see war without the brilliant and accurate alignment of troops, without music, without the drum-roll, without standards flying in the wind, without galloping generals - you will see it as it is, in blood, in suffering, and in death! Leaving this house of pain, you will experience a certain impression of well-being ... glad to find yourself in good health . . . . Besides, in a short time the sight of the pure sky, of the bright sun, of the pretty city, of the open church . . raises your spirits to their normal state. . . Perhaps you will meet on your way the funeral cortege of an officer - a red coffin followed by a band and unfurled standards .... The funeral will only be a pretty picture for you, the growl of the cannon a grand military accompaniment, and 
there will be nothing in common between the picture, these sounds, and the clear, personal impression of suffering and death called up by the sight of the operating room. $(27-28)$

This technique also provides a parting benediction (cum malediction) toward the end of the three-part series, after Tolstoy, shifting gears from journalist to storyteller, takes us so deeply into the psyches of two Russian brothers that we feel them nearly kin only to see both, shortly, doomed to inglorious slaughter: "The sun soared over the gulf, where the water covered with ships at anchor, and with sail and row boats in motion, played merrily in its warm and luminous rays. A light breeze, which scarcely shook the leaves of the stunted oak bushes that grew beside the signal-station, filled the sails of the boats, and made the waves ripple softly" (213). Predictably, only a handful of pages separate this idyll and the havoc-ridden French storming of, first, the Fifth Bastion and, then, the Kornilov Battery, where the Koseltsov brothers, Mikhael and Volodya, respectively, are killed. At one point, like agonizing dissonance blended into mighty crescendo, such as Beethoven creates upon moving from the third to the final movement of his Ninth Symphony, the contrasting elements - peaceful nature and warring man converge in the image of the fusillade that claims Mikhael's life: "The artillery firing had ceased but the clatter of musketry was at its height. The bullets did not whistle as single ones do but came in swarms like a flock of autumn birds flying overhead (198).

This dynamic serves as framework of a study in how man-made physical menace affects human nature, and human nature's time-honored response: mortal fear - in this case, mortal fear under fire. If Tolstoy's Sevastopol Sketches proves a seminal work in the evolution of journalism into fiction, it also marks a psychic shift in the treatment of 
fear, forcing the narrative focus inside characters whom we gradually come to know so that warfare designed to wipe out human life en masse becomes palpable, bothersome, painful and horrific. This modernist technique represents not only a marked departure from most previous narratives set amid armed conflict but also a radical shift in the treatment of humans, and human fear, in battle.

Among the six factors Plamper cites for facilitating soldiers' articulation of fear, the first is the modernization of warfare and the real psychological stress that modern war produces due to far lengthier spans of shooting, shelling and bombardment; the difficulty of establishing the source of an attack, and suppression of the reflex to flee danger occasioned by the immobilization inherent in trench [and bastion] warfare, which marked its debut in the Siege of Sevastopol (261). On an historical timeline, the Crimean War was the first to fit old-fashioned values into modern military garb. The stern martial mentality infused by Field Marshal Alexandr Sorarov, on the one side, and the dutiful, selfless, ethic so valiantly expressed by Alfred Lord Tennyson's “Charge of the Light Brigade" (which occurred in Balaklava, south of Sevastopol, prior to the nearly year-long siege of the latter city) on the other, ran up against the Industrial Revolution's most lethal might - including the Minié rifles borne by the French and British forces (compared to much shorter-range Russian flintlock muskets); the first widespread use of a devastating slashing device bearing the last name of British Gen. Henry Shrapnel, and 5 million bombs and shells of various caliber ... [making it] the earliest example of a truly modern war - fought with new industrial technologies, modern rifles, steamships and railways, novel forms of logistics and communication like the 
telegraph, important innovations in military medicine, and war reporters and photographers directly on the scene. (Figes xix)

To a $21^{\text {st }}$-century readership familiar with PTSD, televised "Shock and Awe," and live video steaming of Middle Eastern barrel bombings and beheadings, Tolstoy's vivid, searing descriptions of combat and its carnage, although antique, perhaps, in being viewed through the pen, nevertheless, appear right at home (like a grandfather in his nephew's house) because akin in their immediacy to those rendered by modern-day techniques. Plamper explains this in terms Marshall McCluhan might have authored: "Moving media such as narrative text and especially film are ideal for the creating of suspense and fear" (263).

The pioneering quality of these descriptions is best appreciated upon considering the holy grail of tsarist military might, which acknowledged fear in its suppression, if not outright obviation. The revolved around Suvorov's teachings. Famous, as was Alexander the Great, for never losing a battle, Generalissimo Suvorov, among Russian military officers, was synonymous with Nauka pobezhdat (The Science of Victory). As V.P. Prasalov notes in an epigraph to Jan Plamper's Fear: Soldiers and Emotions in Early Twentieth-Century Russian Military Psychology, "[t]he main feature of the Suvorov school of drill was the eradication from the heart and banishment from the human head not just of the emotion of fear, but of the very idea of this feeling, which is so disgraceful for the soldier" (259). Plamper describes this traditional mindset as instilled in the Russian serf, the only foot soldiers in Tsarist battles (including Sevastopol), and aristocratic officers: 
Looking for the emotion of soldierly fear in first-person accounts of the War of 1812 resembles the proverbial search for a needle in the haystack. One is more likely to discover overt absences, which sound like this comment made by officer Mikhail Petrov: "Yet the Russian soldiers looked at the huge enemy hordes with an unflinching spirit. With Faith, Hope, and Love, and with the Great Suvorov implanted in our hearts, our souls were prepared for sacrifices to save the Fatherland. (259)

Tolstoy captured and celebrated this mood in a Nov. 20, 1854, letter to his brother Sergei, penned shortly after his arrival in Sevastopol:

The spirit in the ranks beggars all description. Not even in ancient Greece was there such heroism. When [Vice-Admiral Vladimir Alexeyivich] Kornilov rode through the troops, instead of the usual salute he said: "You will have to die, boys, die!” And the troops yelled back: "We will die your Excellency, hooray!!” And this was not said for effect. On the face of every one of the men you could see he was not joking but in real earnest, and 22,000 have already kept their word (A. Tolstoy 66).

A nearly verbatim passage appears toward the end of the author's introductory dispatch, written after an initial week-long stay in the beleaguered city. "Sevastopol in December" is characterized by a reportorial, patriotic tone markedly different from the two subsequent sketches. However random the three-series format may have been in its conception, it works to dramatic effect in the hands of an author dedicated to that hero he, at the close of the second sketch, so acclaims: "the Truth." The truth of war and death evolves from outside observation to an increasingly inner, personal experience of both as, 
"[f]or the first time, the gray masses of officers and men - cannon fodder - are brought to life and the reader, despite himself, comes to care about the fate of these Ivans and Pyotrs; he begins to share their sufferings and joys, to live with them" (A. Tolstoy 71). This increasing intimacy proceeds in step with a deepening descent into an abyss of violence, horror and death whose immediacy, crudity, atrocity and finality, witnessed by the author at the Fourth Bastion (which received the brunt of the French bombardments) between early April and mid-May of 1955 changed his entire tone and converted him into a lifelong pacifist, whose condemnation of war and injustice inspired such moral beacons as Jane Addams, Bertrand Russell, Mahatma Gandhi, Martin Luther King Jr., and Nelson Mandela.

The three dispatches were first published in St. Petersburg's heralded Contemporary literary magazine, founded in 1836 by, among others, the country's preeminent and most-beloved poet, Aleksandr Pushkin, (A. Tolstoy 75). The first sketch, described by Eikhenbaum as a "programmatic preface to the following sketches," differs from them in six main ways: The first and second differences pertain to the narrative voice: The piece is penned in what E.B. Greenwood calls "the dramatic present and the second person (grammatically rare in fiction except in the epistolary form)" rather than the traditional past tense and third person, respectively (32). Both lend immediacy to the reportage, establishing a unique genre in itself. Third, it has no named characters, which lends it an analytical and objective tone, albeit a decidedly Russian one, since, the collective enemy is often called, simply, "he" or "'him,' as the sailors and soldiers say" (25). Description is key and the only parallels to the "inner monologue" that pervade the second two sketches arise from "your" reactions to the extraordinary sights the narrator, 
himself, beholds as reader's proxy - "you." “There are no character types or narrative complications," Greenwood notes; "If we normally thought of journalism as truthful, dignified and restrained, we could certainly call this sketch journalism” (32).

The reading experience resembles being taken by the elbow through a sump of slaughter, surreal in any world that honors human life, by a clear-eyed witness who extracts with eerie detachment the experience of living amid constant cannon and rifle fire and the subsequent carnage. C.S. Lewis describes this plotless narrative approach as a celebration of the loftier aspects of the novel, as E.M. Forester defined them:

I thought the strong narrative lust, the passionate itch to see "what happened in the end" which novels aroused necessarily inured the taste for other, better, but less irresistible forms of literary pleasure....Tolstoy, in this book, has changed all that. I have felt everywhere ... that sublime indifference to the life or death, success or failure, of the chief characters, which is not a blank indifference to all, but almost like submission to the will of God. (Wilson 118)

The fourth element is the decided patriotic tone that prompted Sergii Plohky, remarking on the "Sevastopol myth" that persists to the present day, to deem Tolstoy "its best-known propagandist" (376). Merely being in the city under siege as it suffers constant bombardment proves a heady prospect to the narrator: "At the thought that you, you also, are in Sevastopol, your whole soul is filled with a sentiment of pride and of valor, and your blood runs quicker in your veins" (82). Both civilians and soldiers casually defy death to defend Russia from invaders responding to Tsar Nicholas I's aggressions abroad. The tables turned, the Russians tap the patriotic spirit they had shown 
in defending Moscow against another French invasion four decades earlier. Tolstoy steps directly into the theater, where

[c]onditions ...were appalling. He was only a week there on this visit and frequently got lost among the labyrinth of batteries. There were five hundred big caliber guns facing the enemy to the south. Almost more than the military scale of the operation, Tolstoy was impressed by the spirit of the place. . . The dying and dead lay everywhere. Women and priests brought them water, sacrament, comfort. A dogged willingness to die rather than surrender had taken possession of them all. (Wilson 108)

This spirit is personified by sailors threatening to mutiny should they be removed from a bastion in which they had served more than a month under constant bombardment. In what had been the city's Assembly Hall, now a hospital filled with amputees and reeking of death, a sailor who had lost a leg at the Fifth Bastion contemplates how to contribute further to the cause. "not being able to serve any more himself, .. . he would like to come back to the bastion to train the conscripts" (86). Hearing this noble, improbable wish humbles the narrator, as it astounds him:

You begin now to understand the defenders of Sevastopol, and for some reason begin to feel ashamed of yourself in the presence of this man. You want to say too much, in order to express your sympathy and admiration, but you can't find the right words . . . so you silently bow your head before this taciturn and unconscious grandeur and firmness of spirit - which is ashamed to have its worth revealed. (86) 
Noting the degree to which it extols the Russian soldier in the "Epopee of Sevastopol," whose "hero is the Russian people," Gierigk concludes: "The overriding patriotic mood here is passed on to the narrator like an infection" (247). Patriotism's relevance to this thesis derives from its contribution to what Gierigk, citing Friedrich Nietzsche, terms "the aesthetic condition" (der aesthetische Zustand) conducive to prosecuting war, which requires suppressing fear by invoking images of heroic and glorious deeds (243).

Fifth, Tolstoy had the tsar on his side after publication of the first Sevastopol Dispatch, in which he had described the courageous civil response to daily bombardment and death in words that brought tears to the eyes of Russia's leading man of letters, Ivan Turgenev, and the Tsarina, Maria Alexandrovna, herself. His wife's tears prompted the recently enthroned Alexander II to commit the ultimate act of irony: having those words translated into French so his courtiers could read them in the language of their principle enemy. A.N. Wilson finds a parallel in the outpouring of patriotism during England's moment of ultimate peril nearly a century later:

The first of the sketches is moving in the way that accounts of London during the Blitz are moving: "Men could not accept such conditions of life for the sake of a cross, or promotion, or because of a threat: there must be some other and higher motive power." The patriotic fervor of "Sevastopol in December 1854" greatly appealed to the wartime readers of The Contemporary back in St. Petersburg. The new emperor, Alexander II, actually commissioned a translation into French what a significant gesture that! For all its Russian piety, the tale would only speak to half the courtiers in the language they themselves used. (115) 
The tsar's appreciation of this sketch would be shared by Russia's post-Romanov rulers, who invoked its spirit in what Russians continue to call "The Great Patriotic War" - World War II. As Moss noted, the patriotic tone Tolstoy assumes in this section, especially, would inspire Moscow to call on its strength nearly ninety years later, when "[1]ess than a month after the Nazi government launched its attack on the USSR, the Soviet government reprinted 150,000 copies of [the Sevastopol Sketches] (255).

The sixth, and final, distinction of the first sketch lies in the treatment of the topic of this thesis, fear, which proves an ancillary, not a predominant, theme. Its patriotic tone introduces an amalgam further developed in the subsequent sketches: a sense of sport in courting danger that makes a death wish pale in comparison. Tolstoy, who had already fought in the Caucasus, expresses a young man's excitement at finding himself in the perilous crucible of his people's fate as a nation. Thus, upon first hearing "the grand roar of the cannonade, which seems to increase in strength as you listen," your whereabouts weighs upon you. The second-person technique properly deemed by Greenwood the "dramatic present" never served more dramatic purpose than in these early passages, as the narrator, seemingly pushing you before him, heads to the dreaded Fourth Bastion, infamous among townsfolks as a "certain grave" and among soldiers for "the yellow, liquid stinking mud, more than knee deep" that fills the trenches leading there, forcing them to take the road and expose themselves to bullets, bombs and shrapnel (90).

Closer to the Fourth Bastion, the range of sounds produced by projectiles captivates the narrator, while the roar of the shell-spewing batteries scares him - or "you" - to death. As danger grows more immanent, fear invariably follows, and "your small inward voice, the cowardly counsellor" arises within you (91). 
You seem to hear the noise of a cannonball falling only two yards away, and from all sides come the sound of balls, which sometimes hum like bees, sometimes groan and split the air, which vibrates like a violin string, the whole dominated by the sinister rumbling of cannon, which shakes you from head to foot and fills you with terror. (91-92)

Arriving at the redoubt,

"you will experience interesting sensations and see interesting sights....

[These include] the regular and rather pleasant whistle - which it is difficult to connect with the thought of anything dreadful - of a bomb; you will hear this whistle coming nearer and faster towards you, then you will see a black ball, feel the shock as it strikes the ground, and will hear the ringing explosion. The bomb will fly apart into whizzing and shrieking fragments, stones will rattle in the air, and you will be bespattered with mud. (94)

Scratching the psychic surface, the narrator acknowledges a thrill in skirting bombs similar to that a matador must feel in turning veronicas around a raging bull. Hungarian psychoanalyst Michael Balint calls this sensation Angstlust, which Plamper translates as "a strange blend of fear and enjoyment" (264). Except for those prone to prudence, danger, first encountered, likely evokes this reaction from those it fails to cow or emotionally cripple. As Tolstoy expounds on the feeling, he depicts - or, better, confesses to - the split psyche of a young man eager to test his mettle, yet smart enough to realize that such audacity may cost him his life:

At these sounds you will experience a strange feeling of mingled pleasure and fear. At the moment you know the shot is flying towards you, you are sure to 
imagine that it will kill you, but a feeling of pride will support you and no one will know of the knife that cuts at your heart. But when the shot has flown past without hitting you, you revive and are seized, though only for a moment, by an inexpressibly joyful emotion, so that you feel a peculiar delight in the danger - in this game of life and death - and wish the bombs and balls to fall nearer and nearer to you. (94)

Skirting danger has its thrills for a time, but seeing the impact of one of those shells on a sailor for whom "the knife that cuts at your heart" proves more than metaphoric shakes awake both narrator and reader. After a sentinel's warning of an incoming mortar and the now-familiar whistling, thud and explosion, "you are startled by a man's groan" and see the fellow smeared in blood and earth, resembling "a strange, scarcely human" figure; "[p]art of his breast has been torn away. For the first few moments only terror and the kind of feigned, premature look of suffering, common to men in this state, appear on his mud-besprinkled face" (94). Stretcher bearers carry him off but not before he stops them to bid farewell to his battery mates, saying in a quaking voice, "Forgive me, brothers!" (94-5) Noting "the look of horror on your face," the naval officer in charge quips "That's the way with seven or eight every day," then yawns as he sets about rolling a cigarette (95). The officer's nonchalance - surely the result of facing, and tending to, death on a near-daily basis - is contracted by the narrator, making him immune to the danger around him. Although the same menacing sounds split the air on the way into town, after having witnessed "the defenders of Sevastopol where they are defending it...somehow you return with a tranquil heightened spirit, paying no heed to 
the balls and bombs whose whistles accompany you all the way to the ruined theatre. $(95)$.

Sevastopol in May 1855

"Abstract words such as glory, honor, courage, or hallow were obscene beside the concrete names of villages, the numbers of roads, the names of rivers, the numbers of regiments and the dates."

- Ernest Hemingway, A Farewell to Arms (185)

Toward the close of his first sketch, Tolstoy describes the powerful spirit that enables the defenders of Sevastopol "to live so quietly under the flying balls, exposed to a hundred chances of death besides the one all men are subject to - and this amid conditions of constant toil, lack of sleep, and dirt" (95). The author then hints at a human weakness upon describing its selfless antithesis, as evinced in these humble actors: "Men could not accept such conditions of life for the sake of a cross, or promotion, or because of a threat: there must be some other and higher motive power" (95).

The adjectival form of this frailty appears in the title of one of the most detailed accounts of the Crimean conflict, The Vainglorious War, which describes the engagement largely from the British and French perspective. Nevertheless, instances of this sentiment pepper the pages of "Sevastopol in May 1855" from the very start, when "a tall infantry officer with a slight stoop, drawing on a presentable though not very white glove," reflects on a letter he has received from a former comrade, now retired, and his friend's pale, blue-eyed wife, Natasha or "Pupka" (98): 
When we receive the Invalide [The Army and Navy Gazette], Pupka ... rushes headlong into the hall, seizes the paper and runs with it to a seat in the arbour or drawing room ... and reads of your heroic deeds with an ardour you cannot imagine. 'There now,' she says, 'Mikhalylov is a darling. I am ready to cover him with kisses when I see him. He is certain to receive a George's Cross, and they'll all write about him in the papers' etc., etc. so that I am beginning to be quite jealous of you. (98-99)

With no indication of Mikhalylov's having yet seen action, his friend's words, however well intentioned, should come as the grossest hyperbole. The letter, however, continues in the same misguided vein, based on news from "a fresh arrival from Petersburg ... a capital fellow, sent by the Minister on special business [who] tells us for certain ... that we have taken Eupatoria [so that the French are cut off from Balaklava] and that we lost two hundred in the affair and the French as many as fifteen thousand. My wife was in such raptures that she caroused all night and said that a presentiment assured her that you distinguished yourself in that affair. (99)

The September 17, 1854, landing at Eupatoria - the Anzio or Normandy of the Crimean War (except that the landing went unopposed) - enabled the allies to obtain a foothold on the peninsula, atop the Bay of Kalamita, some 45 miles north of Sevastopol by land. Five months later, the port city came under Russian attack because the tsar, pulling the strings from St. Petersburg, feared a new invasion might cut off the Crimean peninsula from the mainland at the isthmus of Perekop (Figes 321). This strategy proved misguided, as allied artillery backed up a motley Ottoman force of nearly 20,000 under 
the command of Serbian-born Gen. Omar Pasha, who had repelled the attack on the Danubian city of Silestra (which Tolstoy had witnessed from afar and so rapturously described in a previously cited letter to his brother). Pasha, in Eupatoria, led his men to a similar rout, making the battle "a fiasco" for the Russians, with more than eight hundred ... dying in three hours of one-sided action before [Lt. Gen.] Khrulov had to retreat (Royale 336). Figes nearly doubles the number of Russian dead within the same period, noting that the Russians were forced to withdraw across the Crimean Prairie Lands toward Simferopol. With no shelter handy, many died from exhaustion and exposure, their frozen corpses scattered on the steppe (321).

A Russian artillery officer, three months after that February 17, 1855, encounter and nearly fifty miles south of where it had occurred, should have found obscene such sunny assessments of so grievous a slaughter - one that led to not only Russian Army Commander-in-Chief, Prince Alexander Sergeevich Menshikov’s dismissal, but, arguably, the death of Tsar Nicholas I, himself, who had "insisted that the attack ... go ahead, despite his field commander's resignation due to his conviction that it would fail" (Figes 321).

Badly shaken by the defeat at Evpatoria, on the advice of [his Germanborn personal physician Dr. Martin Willhelm von] Mandt, Nicholas handed over the government to his son, the Tsarevich Alexander. ... [E]verybody knew that Nicholas had himself to blame for having ordered the attack, and he was filled with shame. According to Mandt, who was with him when he died, the Tsar's spiritual suffering broke him more than his physical illness, and news of the 
reverse at Evpatoria 'struck the final blow' to his already failing health." (Figes 322)

In one of history's cruel ironies, the man who had deemed the Ottoman Empire "the sick man of Europe" took sick and died from his pig-headed insistence on assaulting what had grown from an Allied bridgehead to an Ottoman encampment. Cruelest of all, the irony was probably not lost on the author of that time-honored phrase. Additionally, the friend's letter to Mikhaylov contains a glaring mistake regarding a material fact that any lieutenant, much less captain, worthy of the rank should have quickly spotted: Even had the Russians seized Eupatoria, it would in no way have cut off the French from Balaclava, some 10 miles south of Sevastopol. That would be like saying the taking of West Palm Beach has cut off an army invading Miami from Key Biscayne when their greatest concentration already lies in Little Havana, from which the shelling of downtown is taking place. The reader is left fearing how an officer so confused about the geography of his own country might aim a musket he intends to shoot at the foe.

Tolstoy, an officer who had traveled overland from Chisinau across Bessarabia to Kherson, just above Crimea, and on to the peninsular capital of Simferopol, must have known the topography well. Later, after serving six weeks at the Fourth Bastion, he was removed to the Belbek River, to the north of Sevastopol. In other words, the author had his bearings straight, and such a mistaken material fact, as well as so skewed a casualty count, could have entered the text only with his full knowledge and intent. The fact no biographer or critic I have read has mentioned this discrepancy shows the reference so subtle as to be virtually buried. In fact, Mikhaylov's failure to notice this egregious error makes him personify, at least by half, a Russian military command marked by what Figes 
calls "corruption and incompetence" (443). Steeped in representations so eminently contrary to the facts, the scene shows Mikhaylov's dire capacity to be duped; it also prepares readers for his capacity to be flattered and fall victim to the evil spell of the military, which, in Gierigk's words,

alienates individuals from themselves in such a way that they refuse even to acknowledge their own experience.... It sets loose exactly that which Nietzsche called the "aesthetic condition" - the ecstatic abandonment to recklessness, heedless of all danger.

Tolstoy, though, fights against the "aesthetic condition" because, under its spell, individuals cease being "guardians" (in Plato's sense). Caught up in such zealous delirium, the enraptured lose all warning signs of reason. With every sinew of his imaginative power, Tolstoy battles the human tendency to aestheticize reality and accommodate oneself to the reality of appearances. As meant here, aestheticizing is not restricted to a measured and, hence, leisurely reception of reality, but emerges primarily in action: It motivates through dreams of heroic deeds, of distinction! (243)

The hapless, unwitting officer, in other words, takes the aestheticized bait served up by his misinformed correspondent; shortly, he succumbs to musings as removed from reality as is the Ministerial envoy's assessment of the action at Eupatoria, not to mention that city's location vis-a-vis Balaklava. Having introduced this perilous pastime, which dominates the second of the Sevastopol Sketches, the narrator allows the aesthetic condition to overtake Mikhaylov completely before delivering him a subtle, mellifluous, white-gloved slap in face: 
[F]rom these recollections, [he] involuntarily passed to dreams and hopes. 'How surprised and pleased Natasha will be ... when she reads in the Invalide [The Army and Navy Gazette] of my being the first to climb on the cannon, and receiving the St. George! I ought to be made full captain on that former recommendation. Then I may easily become a major this year by seniority, because so many of our fellows have been killed and no doubt many more will be killed in this campaign. Then, there'll be more fighting and I, as a well-known man, shall be entrusted with a regiment ... then a lieutenant colonel, the order of St. Anna ... a colonel ... and he was already a general, honouring with a visit Natasha, the widow of his comrade (who would be dead by that time according to his day-dream) - when the sounds of the music on the boulevard reached his ears more distinctly, a crowd of people appeared before his eyes, and he realized that he was on the boulevard and a lieutenant-captain of infantry as before. (98) This second sketch takes a new, disturbing tack on the action, which invited heavy-handed censure due to its "ridicule of our brave officers, the brave defenders of Sevastopol"; nearly unrecognizable, its original published form resembled a piece of Tsarist propaganda (Simmons 132). Such horror as that of the hospital scene that opened the first sketch and marked a radical departure from war writing until then becomes yet more palpable as the narrator heads to the front - the Fourth Bastion - the source of the maiming and pain. No longer is the focus on Sevastopol's everyday citizens, whose spirit is so roundly celebrated in the first. Nor are common soldiers - invariably serfs, who were freed only six years after this war ended - much depicted. The focus, instead, turns onto officers, such as those Tolstoy knew as an artillery lieutenant-captain, and their 
haughty, often frivolous, attitudes with death on the doorstep. This self-assurance and aplomb while pacing the boulevard contrasts so utterly to the primal dread, panic, and alarm soon to beset them as to resemble a chiaroscuro profile of terror rendered in black against a background made from an officer's torn, white glove. By making them seem in control of their fates, this social posturing heightens the subsequent horror of finding them stripped to their essence, their bodies and lives suspended on a thread a stray piece of shrapnel could instantaneously sever. Examining their pretentions, then, better helps appreciate their fears.

One-upmanship and snobbery remain the cruelly hierarchical rule a generation after Nikolai Gogol - in Dead Souls, "The Overcoat," and "The Nose" - "portrayed the imperial state, with its uniforms and ranks, as a Moloch which destroyed people's lives" (Hosking 149). Tolstoy's observation of these airs and affectations, juxtaposed with the action awaiting, lends this work the force of an uppercut to the unsuspecting. If the serfs in the bunkers, redoubts, and mud-filled trenches have it rough, nor are things so easy on "the boulevard," where Mikhaylov has to navigate as many social slights as bullets and bombs on the busiest bastion. He spots a group of white-gloved fellow-officers, but "[n]o one was particularly glad to meet [him] except perhaps Captain Obzhogov of his regiment and Captain Suslikov who pressed his hand warmly" (Tolstoy 100). This fellow feeling Mikhaylov, nevertheless, dismisses due to the sartorial shortcomings of the former and the raucousness of the latter. He, hereby, shows himself to be a zealous social climber: "[T]he first of these wore camel-hair trousers, no gloves, and a shabby overcoat, and his face was red and perspiring, and the second shouted so loud and was so free and easy that one felt ashamed to be seen walking with him, especially by those white-gloved 
officers - to one of whom, an adjunct, Mikhaylov bowed" (100-101). Despite the peril surrounding Sevastopol, the newcomer's yearning to join that white-gloved coterie prompts his first bout of fear, and the first mention of that emotion in this sketch: "But why is Lieutenant-Captain Mikhaylov afraid and unable to muster courage to approach them? 'Supposing they don't return my greeting,' he thinks, 'or merely bow and go on talking among themselves as if I were not there, or simply walk away and leave me standing among the aristocrats?'” (101)

This last term presents Tolstoy an opening to take a well-aimed shot at the trickledown snobbery that was "the reality of the court and ... estates, where most relationships were unadornedly hierarchical" (Hosking 261). Himself to the manor born, Tolstoy chides a social system based on what he considers the worst human impulse:

The word aristocrat (in the sense of the highest and most select circle of any class) has lately gained great popularity in Russia, where one would think it ought not to exist. It has made its way to every part of the country, and into every grade of society which can be reached by vanity.... And since there are many men, and consequently much vanity, in the besieged town of Sevastopol, aristocrats are to be found here too, though death hangs over everyone, be he aristocrat or not.

Social interaction becomes a formulaic equation dependent on gloves, poses, and connections. The poseurs, themselves, were, perhaps, not to blame, since, as Rosamund Bartlett notes, "No one in the nobility could avoid being hierarchically classified in the table of fourteen ranks that Peter the Great had originally instituted for the court, the civil service and the armed forces, [leading] to an obsession with official status which was 
subjected to magnificent ridicule by Gogol in The Nose (1836)" (90). And, one might add, by Tolstoy nineteen years later in "Sevastopol in May." Hence, on the boulevard, "[t]o Captain Obzhogov, Lieutenant-Captain Mikhaylov was an aristocrat, and to Lieutenant-Captain Mikháylov, Adjunct Kalugin was an aristocrat, because he was an adjutant and intimate with another adjutant. To Adjunct Kalugin, Count Nordov was an aristocrat, because he was an aide-de-camp to the Emperor" (101).

Tolstoy here focuses on the fates of four of these individuals, along with that of a haughty, boastful cadet named Baron Pesth. This vertical class structure, a veritable pillar of human vanity, will soon assume a horizontal alignment resembling that described in Blackwood's magazine by British $1^{\text {st }}$ Division gunnery officer Edward Hamley after the early November 1854 Battle of Inkerman:

Few sights can be imagined more strange and sad in their ghastliness than that of dead men lying in ranks, shoulder to shoulder, with upturned faces, and limbs composed, except where some stiffened arm and hand remains pointed upward. The faces and hands of the slain assume, immediately after death, the appearance of wax or clay; the lips parting show the teeth; the hair and the mustache $[s i c]$ become frouzy $[s i c]$, and the body of him who, half an hour before, was a smart soldier, wears a soiled and faded aspect. (Royle 290)

After making a couple of turns past "his aristocrats," Mikhaylov forces himself to approach and engage them, providing the narrator a chance to introduce the characters who will fill the next 30 pages. Their fates will be separately examined here in terms of the three-phase military mentality Gierigk so insightfully identifies, and so roundly condemns: when "prior to battle, the dream of heroism overleaps reality; during battle, 
the bottom falls out of the heroic vision; and, after battle, narcissism falsifies experience, transforming it into a self-serving affirmation, as found in the personal anecdotes of the miles gloriosus (“Swaggering Soldier”) (251).

When we first meet these characters, we find them standing on ceremony and as on guard socially as they soon will be militarily. Mikhaylov, for instance, delights in the fact Kalugin, in high spirits after having curried favor with a general, did not think it beneath his dignity to shake hands with [him], which was more than Praskukhin did though he had often met Mikhaylov on the bastion, had more than once drunk his wine and vodka, and even owed him twelve and a half rubles lost at cards. Not being well acquainted with Prince Galtsin he did not like to appear to be acquainted with a mere lieutenant-captain of infantry. So he only bowed slightly. (102)

As do his descriptions of nature, Tolstoy's portrayals of these closely measured social interactions serve as a foil to the horror to come. The juxtaposition between their pretentious behavior on the boulevard and their primal, fear-induced actions under fire lends this sketch a dynamism steeped in disbelief. The effect on Mikhaylov of being among those he considers his social superiors proves immediate and pernicious. Headed for duty that night, he goes from inquiring seriously about the action on the bastions to joining the others in skirt-chasing just to curry favor - this, despite his being "superstitious and consider[ing] it a great sin to amuse himself with women before going into action; but on this occasion he pretended to be a roué" (103). Going against his moral code to rub shoulders with these "bonjourists" -affected, French-speaking Russian officers Tolstoy first derided in The Wood-felling, a tale of the Caucasus penned shortly 
before the Sevastopol Sketches - Mikhaylov hangs around until dismissed in the rudest of fashions, which he, like a lapdog, accepts without offense: "[He] found it so pleasant to walk in this company that he forgot the nice letter from $\mathrm{T}$ - and his gloomy forebodings at the thought of having to go to the bastion. He remained with them until they began talking exclusively among themselves, avoiding his eyes to show he might go, and at last walked away from him" (104).

Social conventions so calculated and heartless could make one almost yearn for the bastion - if only for the enemy's sincerity in attempting to erase one's existence. Here, it is done by gestures, silences, and snubs. Yet, flattered to the fullest, Mikhaylov heads home to gather his gear before reporting for duty. His ramshackle digs and drunken batman, Nikita, have a sobering effect, and "[he] had hardly crossed the threshold of his lodgings before very different thoughts entered his head" (105). The rug is pulled out from under his heroic poses. Shortly, Mikhaylov is seized by fears, as they, like rats, emerge from every corner of his mind:

"I shall certainly be killed tonight," thought he, "I feel I shall. And there was really no need for me to go - I offered to do it of my own accord. And it always happens that the one who offers himself gets killed... Why, I am going to the bastion for the thirteenth time. Oh, dear, the thirteenth! Unlucky number! I am certain to be killed. I feel I shall. . . I have a presentiment," (105)

Mikhaylov's dread, however, hardly precludes vainglorious musings, as even this troika of rationales for his impending doom fails to contain his conceit. Next door to his self-immolation, self-aggrandizement resides, such as that once incited by hearing word of the admiration felt for him by Pupka, whom he has since forgotten. Just as nothing can 
sedate the sense his time has come, little can restrain his self-adoration: "Still, if they don't kill me I shall certainly be recommended for promotion. I saw how pleased the regimental commander was when I said: 'Allow me to go if Lieutenant Nepshisetski is ill.' If I'm not made a major then I'll get the Order of Vladimir for certain" (105).

This train of thought, soon to become a leitmotif, directly contradicts the morale Tolstoy describes in the first-sketch paean to the selflessness of Sevastopol's everyday sailor and civilian defenders, fueled by a "higher motive power" (95). Mikhaylov returns to earth, as he had so violently when we first met him, vaingloriously inflated, approaching the boulevard; additionally, the narrator commiserates with him in his bout of Angst, making the officer, despite himself, appear more human: "The lieutenantcaptain forgot that it was not the first time he had felt this presentiment: that in a greater or lesser degree he felt it whenever he was going to the bastion, and he did not know that before going into action everyone has such forebodings more or less strongly" (105).

Shortly, his duty-bound conscience turns a light onto his fears, making them scatter back to their subconscious holes, and he sits down to write a farewell letter to his father, "which he finished ... his eyes wet with tears and repeating mentally all the prayers he knew" (105). Setting out for the bastion, his thoughts take a relatively lighthearted turn before, again, growing somber: "But perhaps I shall only be wounded.... But where and how? Here or here? ... Supposing it's here (he thought of his thighs) and goes right round.... Or goes here with a piece of a bomb, then it will be all up" (106). This first foray into the workings of a character's mind as he contemplates battle harbingers what is to come. As these high-born characters abandon the boulevard and enter into a bloody losing cause, Eikhenbaum notes, "the dialectic of the soul ... is developed into a 
complete system ... a series of interior monologues exposing the hidden mechanism of each character's psychic life. All of the characters - Mikhailov, Prashkukin, Kalugin, Geltsin, Pesth - pass in succession through Tolstoi's chemical process (107).

This "chemical process," corroding the mask, proves the distinguishing characteristic of the second and third Sevastopol sketches, as well as a milestone in narrative technique. Tolstoy's strategy appears to be, first, fashion the mask on the boulevard, then tear it off at the bastions, where fear comes to the fore. Trying to pinpoint its power, Gierigk, takes a rhetorical turn upon asking, "What is it that lends such a punch to Tolstoy's testimony about the Russians in the Crimean War? His answer, interestingly, also invokes a scientific process, applying it, as Eikhenbaum does, to human behavior:

Quite obviously, the special generality...is, here, made specific: amid the situation of men at war Tolstoy puts before our eyes the situation of men in the world as if under a microscope. Death, which awaits everyone at any time, in a time of war, becomes simultaneously possible for everyone caught up in it. In war, death appears among the human collective as a "boundary situation" (Grenzsituation) (in Karl Jasper's sense of the word). Everyone is, thereby, drawn into one and the same boundary situation.

In this way, it becomes eminently possible to observe how humans react in the face of the sudden certainty of death: eminently because, here, through its effect on a group of individuals, different ways of facing the certainty of death are presented separately for each. Tolstoy shows us human beings in their capacity to suppress the unbearable truth and conduct themselves as though what were true 
were not true in the least. Is this worthy of judgment? Tolstoy says: Yes - and this, in the name of an ethos of self-preservation. (241-42)

Following in the footsteps of Stendhal, his mentor, who, in The Charterhouse of Parma, had portrayed the battle of Waterloo largely through the eyes and experience of young Italian nobleman Fabrice del Dongo, Tolstoy, in the second and third sketches, relates how each character, in turn, faces either the fear of death or death, itself. Twice, he even gives parallel views of the same boundary situation - the most gripping one involving an unexploded bomb that lands near two officers who, separately, wonder when it will go off and whether it will kill his comrade or himself. "Thus," Eikhenbaum notes, "Stendhal's comparatively modest method was developed in Tolstoy's hands" (110). This direct entry into the psyche of characters makes their feelings, especially fear, those of the reader.

This sketch's “punch,” to paraphrase Gierigk, also derives from Tolstoy's constant oscillation between deep interiority and affectation. He thrives on not just thematic, but also dramatic, juxtaposition, as exhibited in his shift from the solemn to the pompous, from the anguished depths of a son composing a farewell letter to his father before heading off to battle, to a bonjourist tea party in an officer's quarters, where the index finger squeezing a trigger gives way to the uplifted pinkie on a hand transporting a porcelain cup from saucer to lips. Petersburg gossip sprinkled with bon mots in French accompanies "tea, cream and crackles on a silver tray." Galtsin notices the incongruity of the officer's momentarily coddled life and prompts an exchange reflective of the artillery officers' aristocratic background: 
"Isn't it strange to think we're in a besieged town," said Galtsin, taking his tea to the window, "and here's a pianerforty, tea with cream, and a house I should really be glad to have in Petersburg."

“Well, if we hadn't even that much,' said the old and ever-dissatisfied lieutenant-colonel, the constant uncertainty we are living in - seeing people killed day after day and no end to it - would be intolerable. And to have dirt and discomfort added to it -"

"But our infantry officers live at the bastions with their men in the bombproofs and eat the soldiers' soup", said Kalugin, 'what of them?'

"What of them? Well, though it's true they don't change their shirts for ten days at a time, they are heroes all the same - wonderful fellows." (108) This spiraling insipidity touches bottom upon the arrival of one of those lowly infantry officers with an urgent message.

"I ... I have orders ... may I see the gen ... his Excellency? I have come with a message from General N.," he said with a timid bow.

Kalugin rose and without returning the officer's greeting asked with an offensive, affected, official smile if he would not have the goodness to wait; and without asking him to sit down or taking any further notice of him he turned to Galtsin and began talking in French so that the poor officer left alone in the middle of the room did not in the least known what to do with himself." (108-09) Tolstoy, here, provides a harsh critique of his homeland's rigid, callous caste system, in which the forms of friendly fire include one-upmanship and slights, which, in belittling peers, defy military honor, as evinced later in this scene, when duty obliges the 
messenger - himself, an officer - after a brief pause, to interject, "It is a matter of the utmost urgency, sir.” Only then does Kalúgin take him to see the general (109).

The absence of even an inkling of comradery evident in this exchange can only enhance a soldier's sense of aloneness in the face of mortal danger, thereby heightening his fear. A sense of fellow-feeling emerges only later in the sketch, when a truce is called to clear the bodies filling the ravine that separates the warring sides - here, though, it arises between enemies, bringing the irony full circle.

Gierigk considers embellishing battle before or after the fact, or when viewing it from afar, another instance of "how aestheticizing reality creates an illusory reality" (244). In Galtsin, Kalugin, and Pesth, this tendency is .pronounced. The previously cited letter to his brother Nikolai, in which Tolstoy describes the battle of Silestra from a distant height, shows that Tolstoy, himself, was guilty of the practice. The scene involving Galtsin and Kalugin at the latter's flat closely echoes that instance of "aestheticizing reality in its contemplation" (244). The two are lying on the windowsill at night, watching bombs soar above the bastion to the east amid the ever-increasing popping of muskets and rifles and the fire of cannon lighting up the night sky:

“Quel charmant coup d'oeil, non?" (What a beautiful sight, eh?) said Kalugin, trying to steer his guest's attention to the truly marvelous spectacle. "You know, you can hardly tell the stars from the bombs."

And Galtsin agrees. (244)

Another instance of what Gierigk calls "aesthetic self-oblivion mask[ing] reality in the name of life, which will not acknowledge death" occurs as Kalugin heads off to duty (244). Shortly after an orderly informs him that things are "hot" at the bastion, he 
catches an earful of an enemy cannonade and feels, as had Mikhaylov, a "presentiment a very unusual thought, the thought of death" (Tolstoy 116). As Kalugin summons his courage, what follows, to Wilson,

is funnier, and more touching, than anything in the anti-war propaganda of Tolstoy's late period. "[Kalugin] was ambitious and blessed with nerves of oak in a word he is what is called brave. He recalled how an adjutant, Napoleon's, he thought, having delivered an order, galloped with bleeding head full speed to Napoleon. 'Vous êtes blessés?' said Napoleon. 'Je vous demande pardon, sire, je suis mort,' and the adjutant fell from his horse, dead."

The reader has only recovered from laughing at this sentence when his eye meets the next ... "That seemed to him very fine..." There is the whole absurdity of the patriotic position (116).

Gierigk also regards as worrisome the effect of the adjutant's answer on Kalugin, who "finds this just marvelous and pictures himself a bit like the adjutant, whipping his horse into action and sitting in the saddle even more 'in the Cassock style' [a pretentious way of riding fancied by Russian officers in this sketch]. Here, the aesthetic condition comes into play." (244)

Leaving behind his tea, cream and crackles, Galtsin retains his arrogance as he heads to the bastion. Meeting retreating soldiers, he directly upbraids them for leaving their posts. About to call one a scoundrel, he shouts the first syllable before noticing "that no hand was visible beneath the soldier's right cuff and that the sleeve was soaked in blood to the elbow" (114 ).To his credit, Galtsin feels "horribly ashamed of his unjust suspicions" and, strangely sobered or, possibly, concerned about the condition of some of 
his charges, heads off for the hospital, which he enters but cannot stomach: "it was too terrible" (115). Guided by the author in "Sevastopol in August," readers have already toured the facility and been alternately nauseated and shocked by what they've seen; yet, when an officer, several of whose men are probably patients inside, lacks the fortitude to step in past the entrance, readers get the impression that whatever "prince" is pinned to Galtsin's name has come courtesy of Holden Caulfield.

As Kalugin heads to the bastion, he acts similarly dismissive of the wounded he encounters; "knowing from experience that in action such sights have a bad effect on one's spirits, he did not stop to question them but tried on the contrary not to notice them" (116).Riding on, he finds a soldier resting and scolds him, as Galtsin had the wounded soldier. These two officers, who most aestheticize battle from afar, prove the most judgmental and punishing toward common soldiers. Climbing the hill to the Fourth Bastion, Kalugin's illusions are rapidly stripped, as a shard of shrapnel buzzes past him and lands in a trench. Spotting a second bomb sailing toward him, he feels scared, sprints a few steps, and throws himself to the ground. When the bomb explodes a safe distance off, he berates himself, regains his feet, and looks around to spot who might have seen him dive - thankfully, finding no one (117).

As a leveling factor, death is unparalleled, even making it difficult for an aristocrat in the grave to look down his nose at someone; once it worms its way into a fellow boasting nerves of oak, fear has a like effect, turning him into more of a blubbering dolt than an aplomb-laden boulevard rambler:

[W]hen fear once enters the soul it does not easily yield to any other feeling. He who always boasted that he never ever stooped now hurried along the 
trench on almost all fours. He stumbled, and thought, “Oh, it's awful! They'll kill me for certain!" His breath came with difficulty, and perspiration broke out over his whole body. He was surprised at himself but no longer strove to master his feelings. (117-8)

Vanity saves the day, as the sound of footsteps - hence, potential witnesses to his weakness - brings Kalugin back to his senses; he quickly straightens up, lifts his head, and, "boldly clanking his sabre" (giving audible notice that he is an officer), continues on with new-found resolve. "He felt himself quite a different man," the narrator notes, and, when fellow defenders shout for him to hit the ground and point to a bomb overhead growing brighter and brighter as it hastens to earth and crashes down near the trench, he merely stoops slightly, "involuntarily influenced by the frightened cry" [but not the bomb, itself], and carries on. Nietzsche's aesthetic condition is back in the saddle, riding "Cossack style" (118).

“That's a brave one ... he won't even lie down," a sailor notes, misreading Kalugin's true state as he scampers to the battalion commander's dugout shelter; en route, his mind "again became clouded and the same stupid terror seized him: his heart beat more violently, the blood rushed to his head, and he had to make an effort to force himself to run to the bomb-proof." Both body and soul in the grips of fear as the bottom falls out of his posing, Kalugin, nonetheless, continues his dissembling to save face. When the general asks why he is so winded. Kalugin replies, "I walked very fast, your Excellency!” (118)

Once safely beneath the redoubt's two-foot-thick-beam ceiling, he remains upset by his twice succumbing to "such unpardonable weakness" (118). The military mindset, 
as Gierigk states, "has no room for the fearful [but] simply derides them as "cowards" (245). An officer known for his valor cannot accept this lowly label, and Kalugin readily shows the same eagerness to affront fate as had the narrator in the first sketch, "wish[ing] for danger in order to test his nerve once more" (119).

Right at this juncture, Kalugin's perfect counterpart appears in the person of a naval captain with big moustaches and a St. George's Cross (awarded for "undaunted courage" in combat), whom Kalugin asks to bomb the Allied trenches with special munitions; the captain, having just returned from duty, suggests Kalugin go by himself to speak to the lieutenant who had replaced him at the guns. The narrator makes clear just who this man is: As displayed over the six months since the siege began and before any bomb-proof shelters had even been built, his valor has earned him the esteem of not only his charges but, judging from the medal he bears, also the entire military and imperial establishment. Kalugin, though, grows testy over what he wrongly interprets as a snub and mockingly muses: "So much for reputation" (119). He cannot leave it at that, however, but must make a dig in front of the general and five other officers sitting inside the bunker: “'Well, then I will go alone if I may,' he said in a slightly sarcastic tone to the captain, who however paid no attention to his words" (119).

Tolstoy further reveals the glory-hound's continued embrace of the aesthetic condition by contrasting it to the sober caution of this seasoned veteran, who has been humbled by the hardships through which he has lived and the horrors he has seen:

Kalugin was still actuated by vanity, the wish to shine, the hope of rewards, of gaining a reputation and the charm of running risks. But the captain had already lived through all that: at first he had felt vain, had shown off his courage, had 
been foolhardy, had hoped for rewards and reputation and had even gained them, but now all these incentives had lost their power over him and he saw things differently. He fulfilled his duty exactly, but, quite understanding how much the chances of life were against him after six months at the bastion, he no longer ran risks without serious need, and so the young lieutenant who had joined the battery a week ago and was now showing it to Kalugin with whom he vied in uselessly leaning out of the embrasures and climbing out on the banquette, seemed ten times braver than the captain. (119-20)

Perhaps the most gratifying moment of Kalugin's foray to the front comes when the general dispatches him to establish how work is progressing at the lodgements. Clanking his saber as is his wont (a gesture that serves the same purpose as the regular wrist flicks of certain men who wear gold watches), he heads out under heavy fire and runs into Mikhaylov and Praskukhin. Here, Kalugin, who had hastened to privately chide the captain for refusing to accompany him to examine the guns he had just left after a full night on duty, and competed with the lieutenant in exposing himself to fire on the embrasures, now pulls up short instead of stepping straight into the inferno besetting the lodgments, as a man with nerves of oak, eager to test his mettle, should do. Nothing of the sort. Meeting Mikhaylov, he spots a dodge and ponders: "instead of going there himself under such a terrible fire - which he was not ordered to do - he might just as well find out all about it from an officer who had been there" (122). Thus, after walking a short stretch with the companions he had sauntered beside along the boulevard at the start of the chapter, he veers off into a trench leading back to the bomb-proof, where a solitary officer eating dinner questions him about the action. "Nothing much, Kalugin replies. "It 
seems that the affair is over." "Over?" the other replies. "How so? On the contrary, the general has just gone again to the watch-tower and another regiment has arrived. Yes, there it is. Listen! The muskets again!"' (122).

Kalugin has returned to the bunker empty-handed due to his having questioned an unworthy source distant from the action and failed to confirm his account. While not directly ordered to go to the bastion, were he a diligent officer he would have gotten closer than he had; were he as valiant an officer as he makes himself out to be, he would have died at the doorstep. He seems to suspect as much, but when his conscience pricks, he has a balm handy: "I certainly ought to be there . . . but I have already exposed myself a great deal today; the firing is awful"' (122).

When Kalugin runs into Pesth and notes blood on his coat, the latter gives the work's most vivid account of the mania that besets soldiers in hand-to-hand combat, as well as the sketches' closest study of the "swaggering soldier," who, after the fact, glorifies his role and behavior in battle; Tolstoy, here, assumes a cunning narrative stance that might be described as interjector and record-straightener. "[His] personal role as an author," Eikhenbaum notes, "takes the form of a constant intervention in the conversations and actions of his personages with constant evidence to show what they feel and think in actual fact" (111). Greenfield enlarges on this observation, noting that "inclusive of the minds [of these five characters] and of what they witness is the mind of Tolstoy himself. It is the mind of an omniscient narrator who hears the very thoughts of men and denounces their moral blindness and vanity with the eloquence and authority of a prophet" (33). 
"Oh, it was awful! Just fancy," Pesth says, as he recounts leading his company after their commander had been killed and bayoneting a French soldier to death; "but in recounting the details the cadet invented and bragged" (123). Tolstoy allows for Pesth's exaggerations in this case by deftly describing the psychic shroud that falls to enable engaging in such grisly mayhem:

He bragged unintentionally, because during the whole affair he had been as in a fog and so bewildered that all he remembered of what had happened seemed to have happened somewhere, at some time, and to somebody. And very naturally he tried to recall the details in a light advantageous to himself. What really occurred was this: ... [Ordered to fix the famously deadly Russian three-edged bayonet, Pesth and his comrades advanced.] Pesth was in such a fright that he could not in the least make out how long it lasted, where he went or who was who. He went on as if he were drunk. But suddenly a million fires flashed from all sides, and something whistled and clattered. He shouted and ran somewhere, because everyone shouted and ran. Then he stumbled and fell over something. It was the company commander, who had been wounded at the head of his company, and who taking the cadet for a Frenchman had seized him by the leg. Then when Pesth had freed his leg and got up, someone else ran against him from behind in the dark and nearly knocked him down again. "Run him through!” someone else shouted. "Why are you stopping?" Then someone seized a bayonet and stuck it into something soft. "Ah, Dieu!" came a dreadful piercing voice, and Pesth only then understood that he had bayoneted a Frenchman. A cold sweat covered his whole body, he trembled as in a fever and threw down his musket. But that lasted 
only a moment: the thought immediately entered his head that he was a hero. He again seized his musket, and shouting "Hurrah!” ran with the crowd away from the dead Frenchman. (124)

Tolstoy's repeated use of "someone" here drives home the impersonality of such a violence-sated stupor. The passage vividly portrays what Plamper calls "The Doctrine of Controlled Berserkdom”...a [combatant's] ability to unleash and reign in his aggressions without using modern fire weapons." Devised by decorated Gen. Mikhail Dragomirov who had distinguished himself in triumphs over the Poles, the Prussians and the Ottoman Turks before being wounded and assigned to direct the Military Academy in St. Petersburg - the doctrine derived, on the one hand, from a belief in the universal penchant toward self-sacrifice, be it even through suffering or death. In the case of Russian soldiers this meant a "special loyalty toward fatherland, as embodied by the tsar... and a feeling that goes as far as self-denial." (A scene depicting this spirit appears in a November 20,1854, letter Tolstoy wrote his brother Sergei, cited in the first section of this chapter.) On the other hand, it obtains from a view of humankind originating in the Enlightenment emphasis on reason, since "only an autonomous, rational subject can, on command, start and stop himself from going berserk" (Plamper 269-70).

These precepts, first published as infantry regulations in 1866, came to dominate Russian military training up until World War I, Plamper notes:

With this doctrine, Russia developed an "emotional regime" that openly revolved around fear surprisingly early - with the express goal, of course, of channeling, managing, and ultimately overcoming this fear. Thus Tolstoy's realist fiction and Dragomirov's military theorizing were the first stages in a wider rhetoric of 
soldierly fear. They prepared the ground for early public talk about fear by highranking officers in the aftermath of the Russo-Turkish War (1877-1878). (270-71) How much this sense of self-sacrifice, so evident among the sailors and foot soldiers (largely serfs) defending Sevastopol, was also embraced by officers is open to question, judging from those reclaiming the boulevard, where we had met them at the outset of "Sevastopol in May." As the two walk home, Pesth tells Kalugin that Praskukhin has been killed.

"Impossible!" replies the latter; but, when they part, not another thought is spent on his fallen comrade. Rather, the officer's psyche assumes its natural swagger: "This is capital! though Kalugin, as he came to his lodgings. "It's the first time I have had such luck when on duty. It's first rate. I am alive and well, and shall certainly get an excellent recommendation and am sure of a gold sabre. And I really have deserved it." (125)

Easily the most disconcerting scene in this sketch, and the one that most vividly portrays Jasper's "boundary situation" is that in which two of the officers - Paskukhin and Mikhaylov - returning to town from the Fourth Bastion and believing themselves out of danger, suddenly hear the sentinel shout out "Mortar!" A veteran soldier who had come out of retirement to join in the defense of Sevastopol, Praskukhin had made a fatal mistake in failing to order Mikhaylov and his troops to hustle down the hill, the more readily to distance themselves from the French cannons, "which began to fire more and more frequently" (121). He, himself, senses the wisdom of a swift withdrawal from the area, yet pride, a needless manifestation of the aesthetic condition, keeps him from heeding his better judgment: “"What the devil are they so slow for?' thought Praskukhin, 
continually looking back as he marched beside Mikhaylov. 'I'd really better run on. I've delivered the order ... But, no, they might afterward say I'm a coward. What must be will be. I'll keep beside him"” (122).

Invoking fatalism to quiet fear instead of simply eluding danger proves a fateful decision for Praskukhin, whose lingering for appearances' sake after having done his duty in delivering the order puts him right beneath an incoming shell. By the time Mikhaylov looks around, "[t]he bright spot seemed to have stopped at its zenith, in the position that makes it absolutely impossible to determine its direction" (126). Praskukhin hears it fall nearby, amid the battalion, but it fails to explode. "A second passed which seemed like an hour" (126). Even in this situation, despite his righteous fear, Praskukhin remains psychologically entangled in Plamper's "webs of dependence, intent on saving [his] honor" in front of his fellows, the traditional Russian military mentality (262). Yet, saving face can cost one's life, Gierigk hastens to note, when, "focused on what 'others' will think of them, individuals pass over the warnings of reason" (244-45). Praskukhin appears more fearful of being considered craven for seeking cover than he is of the deadly explosive in their midst: "Perhaps he had played the coward for nothing. Perhaps the bomb had fallen far away, and it only seemed to him that its fuse was fizzling close by. He opened his eyes and was pleased to see Mikhaylov lying unmovable at his feet" (126).

This woefully vain observation, assuring Praskukhin he is not the only one to have hit the deck, will prove among his last, because "at that moment he caught sight of the glowing fuse of the bomb which was spinning on the ground not a yard off" (126). 
With the mortal threat an arm's length away, only primeval emotion remains, and "terror, cold terror, excluding every other thought and feeling, seized his whole being” (126).

Tolstoy's "chemical process" is nowhere more intensely applied. Prashkukhin's first thoughts, rightfully regarding the most immediate issue of the bomb's effects on his person, are reminiscent of Mikhaylov's after he had written his father and first headed to the bastion: "Whom will it hit - Mikhaylov or me? Or both of us? And, if it's me, where? In the head? Then I'm done for. But if it's the leg, they'll cut it off (I'll certainly ask for chloroform) and I may survive. But perhaps only Mikhaylov will be hit. Then I will tell how he was killed and I was splashed with his blood. No, it's nearer to me... it will be I" (126). The thought of Mikhaylov brings to mind the twelve rubles Praskukhin owes him, as well as an older debt he has elsewhere, a song he had sung, his girlfriend in "a cap with lilac ribbons," and a man who had insulted him five years previous and not been paid in kind. Alongside these and countless other memories, "the present thought, the expectation of death, did not leave him for an instant" (127).

A more intimate rendering of a person facing Jasper's existential "boundary situation" is hard to imagine. Anticipating the explosion, Praskukhin remains wishful; once it occurs, he remains unaware of its full effect and responds instinctively, trying to flee: '“Perhaps it won't explode,' thought he, and with desperate decision he resolved to open his eyes. But at that instant a red flame pierced through the still closed lids and something struck him in the middle of his chest with a terrible crash. He jumped up and began to run, but stumbling over the sabre that got between his legs he fell on his side" (126). 
Tolstoy accompanies the soldier unto death. First, Praskukhin thinks he is only wounded, yet he can't raise his hand to touch his chest because his arms are as if tied to his sides. Something is squeezing his head. Soldiers speed past him, and he is able to count them - "One, two, three soldiers!" After an officer passes, Prashkukhin aestheticizes a vital sign of impending doom: a series of lightning flashes that he thinks comes from cannons or mortars (127). His only fear is being run over by the soldiers. He tries to shout, but his mouth is too dry, and the wetness he feels in his chest makes him so thirsty that he wishes to drink "even this that made him feel wet" - his own blood (127). Still, Praskukhin insists on aestheticizing his condition. Grasping at psychic straws as the severity of his wound increasingly snuffs the mortal coil, he continues grasping. In narrative terms, Eikhenbaum notes, his death "is described circuitously, as he, himself, does not realize he will die" (108). This creates the sensation of being sucked into a vortex, as Praskukhin, in grotesque Pollyanna fashion, battles reality to the bitter end:

"I suppose I hit myself in falling and made myself bleed," thought he, and giving way more and more to fear lest the soldiers who kept flitting past might trample on him, he gathered all his strength and tried to shout, "Take me with you!" but instead of that he uttered such a terrible groan that the sound frightened him. Then some other red fires began dancing before his eyes and it seemed to him that the soldiers put stones on him. The fires danced less and less, but the stones they put on him pressed more and more heavily. He made an effort to push off the stones, stretched himself, and saw and heard and felt nothing more. He had been killed on the spot by a bomb-splinter in the middle of his chest. (127-28) 
This passage marked an innovation in narrative technique that anticipated the stream-of-consciousness ending of Ulysses. Greenwood draws a parallel to a celebrated device employed by another giant of English literature:

Captain Prashkukin is killed by a bomb and the interior monologue which Tolstoy gives him as he watches it spinning marks an important stage in Tolstoy's mastering the use of this device. The interior monologue will be of great importance in War and Peace and Anna Karinina. It stands in the same relation to Tolstoy's art that the soliloquy stands to Shakespeare's. The Russian critic Chernyshevsky singled out this instance of Tolstoy's use of the device for special attention as a new departure in literature and was the first to use the name 'inner monologue' for it. (12)

The innovation is highly relevant to this thesis, since the technique is the perfect conveyor of fear: raw, unvarnished horror experienced amid conditions beyond one's comprehension and whose incomprehensibility enhances that horror. Letting a character's mind convey such feelings, drawn from perception, lends narrative the immediacy of a knife to the throat. Perception, then, creates a parallel world replete with impressions, which, if harnessed and pinned to a plot, provide the makings of a masterpiece, such as

\section{The Red Badge of Courage.}

The passage's importance also lies in its destroying the canon of the heroic death in war. (This technique or "device" will be employed to even more cathartic effect in the final sketch, whose characters we come to know more deeply.) Since, here, it contributes nothing to the story's plot, Eikhenbaum argues, the fact of death is less important than the ".process of dying" and the device by which Praskukhin is made "an outsider to himself": 
"We note the same external analysis of the psychic life, in this case strengthened by the fact the true sense of everything observed is entirely different. Tolstoy's treatment of Mikhaylov is precisely the same, albeit with a reversed relationship between the psychic life and external reality" (108-09).

Thus, in the second half of this scene, we see Mikhaylov hitting the ground and also "living through an infinitude of thoughts and feelings in the two seconds that elapsed before the bomb burst" (128). The floor having fallen out of his visions of glory, he suffers remorse for having been mesmerized by "the military's evil spell” (Gierigk 240). He turns to prayer and second-guessing, designed, from the narrator's perspective, to undermine the extensive pre-battle braggadocio with which the chapter had begun, including all his posturing for "Pupka": "Why did I enter the army? And why did I join the infantry to take part in this campaign? Wouldn't it have been better to have remained with the Uhlan regiment at T---- and spent my time with my friend Natasha? And now here I am ..." (128)

He, too, starts counting, but not soldiers passing by, which had been indicative of Praskukhin's immobility and demise; rather, he tries to quell his fear by playing a type of children's bingo, “deciding that if the bomb burst at an even number he would live but if at an odd number he would be killed" (128). When the bomb does explode "(he couldn't remember whether at an odd or even number)" he feels a blow to the head and terrible pain and concludes he has been killed. Blood running down his nose and a lessening of the pain reinforce his conviction that he is dead, and he tells himself "[T] hat's the soul passing ... How will it be there?" (128). This query, reminiscent of Hamlet's, prompts more prayer and an odd sensation for a spirit aspiring toward the beyond: "Lord, receive 
my soul in peace! ... Only it's strange ... that while dying I should hear the steps of the soldiers and the sounds of the firing so distinctly" (128). When battalion drummer Ignatyev calls for stretchers, Mikhaylov finally opens his eyes; sees stars in the nighttime sky and bombs racing across it; notices soldiers, guns and trenches nearby, and realizes he was not yet in the other world. ... He had been slightly wounded in the head by a stone. His first feeling was one almost of regret: he had prepared himself so calmly to go there that the return to reality, with its bombs, stretchers, and blood, seemed unpleasant. The second feeling was unconscious joy at being alive, and the third a wish to get away from the bastion as quickly as possible. (129) In terms of the relationship of their respective perceptions to their respective realities, Tolstoy might be said, here, to encapsulate within several seconds of horror the diversely crossing destinies of two characters in a way reminiscent of those of Macbeth and Lady Macbeth in Shakespeare's five-act tragedy. Eikhenbaum notes:

In this contrasting juxtaposition the typical Tolstoian paradox lies hidden, bestranging the traditional "literary" conception of death - especially heroic death. Tolstoi says ... people simply do not die the way it is usually written. Nature is not such as it is portrayed, war is not such ... bravery is not manifested that way, people do not love that way, they do not live and think that way, and, finally, they do not die that way. (108-09)

The sketch ends with a demoralizing denouement back on the boulevard where it had begun, followed by a final benediction unlike any other. Here, we find Kalugin and Galtsin walking arm in arm, showcasing their sorrow, "[b]ut, to tell the truth, as none of them had lost anyone very dear to him, the sorrowful expression was only an official one 
they considered it their duty to exhibit" (132). The masks, now in a pious guise, have been donned anew, but the interjecting narrator proceeds to reveal the self-seeking strivings of these ambitious bonjourists, including all of us among their ranks.

[I]n fact though they were first-rate fellows . . ready to see such an affair every day if they could get a gold sword and be made major-general each time. It is all very well to call some conqueror a monster because he destroys millions to gratify his ambitions, but go and ask any Ensign Petrushev or Sub-Lieutenant Antonov on their conscience, and you will find that every one of us is a little Napoleon, a petty monster ready to start a battle and kill a hundred men merely to get an extra medal or one-third additional pay" (132).

His "chemical process" having exposed the frailties of his characters, the narrator questions whether he shouldn't have, perhaps, left those “evil truths" untouched, "lest they become harmful, as the dregs in a bottle must not be disturbed for fear of spoiling the wine. ..." (137). Had he done so, "Sevastopol in May" would have easily been shortened by half. What his "process" has revealed precludes Tolstoy's depicting any of these characters as good or bad, hero or villain, leaving him to confess, as previously cited: "the hero of my tale - whom I love with all the power of my soul, whom I have tried to portray in all his beauty, who has been, is, and will be beautiful - is Truth" (137). This devotion to "Truth," as experienced both on the boulevard and under fire, proved the justification, as well as the means, for undermining the canon; in doing so, it paved the way for a modernistic approach to war writing that continues to this day. 
Sevastopol in August 1855

Tolstoy the jingoist and Tolstoy the satirist mark the first two Sevastopol sketches, respectively; in the third, the reader comes to know the author in his mostheralded guise: as Tolstoy the humanist, familiar with the workings of fear in a young person who has taken on more than he had bargained for and feels morally compelled to see it through. In this capacity, the author delves into the lives and psyches of two brothers, long parted by the army, who meet at a posting station en route to Sevastopol. Ambitious and energetic, Lt. Michael Kozeltsov seeks to rejoin his regiment after spending months in a Simferopol hospital recovering from a shrapnel wound to the head. His younger brother, Volodya - a winsome, ingenuous youth - has just arrived from the Cadet College in Petersburg, where he had been expected to enter the Imperial Guards but had been caught smoking and received low marks for conduct, which derailed those plans; fused with a sense of duty, he opted to head for battle. Their coincidental encounter enables them to travel together, giving the starry-eyed Volodya occasion to succumb to the aesthetic condition amid extensive musings on how the two, together, will engage the enemy in close combat and selflessly give their lives for the Fatherland. His page-long daydream, extolling his brother's valor and the love he feels for him, is interrupted at the outset by that very person's unwittingly cramping Volodya toward the back of the trap in which they are being jostled and jolted on "the stony road that leads by the Belbek [river] to Sevastopol" (154).

In contrasting the first two Sevastopol sketches, Wilson notes that "the patriotism of the first sketch is tempered in the second ... by a strongly satirical sense of how absurd army life and military vanity can be: also by scenes in which the sufferings of 
wounded men are observed with intolerable vividness" (115). The latter sketch's juxtaposition of bastion gore and boulevard preening makes the reader feel doubly imperiled - on the one hand, by finality, on the other, by banality. "Sevastopol in August 1855 " takes a different tack on the cost of war, showing how it tears out the heart of anyone, including readers, who feel affection for the fallen.

The sketch revolves around human sentiment in the form of brotherly love and comradery as much as the first did patriotic fervor and the second, snobbery and vanity as the flipside of calamity. The ultimate effect of the three-part series could not be more poignant had it been planned - a highly unlikely prospect, given the lapses between the sketches and the uncertainty of whether the author would live long enough to finish the entry on which he was working, much less be around to write a sequel. Fanfare for the Fatherland, the hallmark of "Sevastopol in December," won the Russian heart, including that of the Tsarina, and prompted Tsar Nicholas I to publish it in French for his courtiers to read. A critical send-up of officers beholden to the aesthetic condition, along with what Wilson calls "a tub-thumping expression of amazement that Christian people, seeing the carnage they have done, are pleased, and not as they should be, penitent" characterizes "Sevastopol in May" (116). Little wonder that it evoked a far different response from the imperial court, whose censors trimmed it to shreds, then endeavored to patch it together until it resembled Humpty Dumpty propaganda. Possibly schooled by the censor's attentions, the ingenious Tolstoy - whose first two sketches contained lengthy asides condemning war in lofty, incontestable terms - took his parting shot by appealing to the human heart, creating two characters who readily evoke from readers both fondness and 
respect, then sending them into the late-August storming of Sevastopol, when the bastions were overrun.

The grisly cost of war is there in December 1854, when "you are struck by the sight and smell of forty or fifty amputation and most seriously wounded cases"; it is there in May 1855, when, during a cease-fire a ten-year-old boy gathers blue flowers amid bodies littered across the valley, holds his nose to escape the smell carried by the breeze, and stopping near a pile of corpses stares at one missing its head; and, finally, and most tellingly, it is there in August 1855, when two brothers who become our own enter the grist mill of mechanized warfare (Tolstoy 27).

A Tale of Two Brothers, Doomed

So does the third sketch, depicting a pair of young, noble-minded soldiers caught up in a losing cause, serve as a fitting, if deeply disturbing, culmination to the series and the most harrowing portrait of fear, since we, as it were, live it in the person of a "lad of about seventeen with merry black eyes and very rosy cheeks" first going off to war, and his elder brother, Michael, who has been there, been wounded and hospitalized, and is now heading back (149). The patriotic ardor introduced in the first sketch fuels the breast of Volodya, a freshly minted cadet steeped in admiration of Michael. The latter's name, along with its owner's identifying feature, sound familiar, since "[T]his officer had been wounded in the head by a bomb splinter on 10 May and still wore a bandage (139)." So is Michael Koseltzov reminiscent of Michaylov, who, wounded in the head by a stone, was convinced he would die at the end of the preceding sketch, "Sevastopol in May."

Although they are not the same person - the former being a lieutenant and the latter a lieutenant-captain - the reader is reminded of the reverie in which, so enamored 
of his friend's "pale, blue-eyed" wife "Pupka," Michaylov envisions himself climbing onto cannons to claim her heart, receiving the St. George's Cross for valor, continuing on to become a captain based on that honor, then a lieutenant-colonel with the order of St, Anna, and, finally a general, honoring Pupka, who had by now lost her husband, with a visit. His reverie dissipates as the sound of the music played by the regimental band fills the boulevard. "It reached his ears more distinctly . . . and he realized he was on the boulevard and a lieutenant captain of infantry as before" (100).

The temptation to confuse the two - Michael and Michaylov - is all the greater in light of their respective views of warfare, creating the impression that profound character development had occurred between May and September: Whereas Michaylov had readily ceded to the "military's evil spell," Michael Koslotsov is all business, as if a close encounter with a bomb splinter and a months-long convalescence had screwed his head on right. His grave, rooted attitude serves as a needed foil to Volodya's musings as the latter emerges from a page-long daydream even more extravagant that that of Michaylov's at the start of the previous sketch:

[T]wo brothers, friends with one another, fighting the enemy side by side . . I with the guns and my brother with his company, both together. Suddenly the French will fall upon us. I shall fire and fire. I shall kill quite a lot of them but they will still keep coming straight at me . . there is no escape for me, but suddenly my brother rushes to the front with his sword drawn, and I seize a musket. ... Then my brother falls at my side, shot dead by a bullet. I stop for a moment, bend sadly over him, draw myself up and cry: "Follow me! We will avenge him! I loved my brother more than anything on earth," I shall say. "I have 
lost him. Let us avenge him. Let us annihilate the foe or let us all die here!” They will all rush after me shouting. Then all the French army, with Pélissier himself, will advance. We shall slaughter them, but at last I shall be wounded a second and a third time and shall fall down dying. Then they will all rush over to me. ... I shall say that I want nothing - only to be laid near my brother: that I wish to die beside him. They will carry me and lay me down by the blood-stained corpse of my brother. I shall raise myself, and say only, "Yes, you did not know how to value two men who really loved the Fatherland: now they have both fallen. May God forgive you!" ... and then I'll die. (154-55)

His artistry refined, Tolstoy frames Volodya's runaway vision within three seemingly insignificant incidents that converge to reveal the deep love the youth feels for his brother. The first comes up at the posting station, when Michael proposes they travel together to Sevastopol. Volodya jumps at the idea but gets cold feet "at the thought that after getting into the trap there would be nothing more to detain him and that he would not alight again before reaching Sevastopol ... [only then] did he clearly realize the danger he had been seeking, and he grew confused and frightened at the mere thought of the nearness of that danger" (152-3). A more quotidian matter appears to preclude his joining his brother after Volodya goes into a neighboring room to suggest the idea to his superior officer, and, several minutes later, returns, with a sigh, to tell Michael he can't. "What?" retorts Koseltzov. "What nonsense!" (152-3) Purse strings hold Volodya back, since neither he nor the other cadets with whom he is underway have yet to receive their traveling allowance; hence, they have become indebted to the officer for the cost of the sugar he had sponsored at three posting stations, plus their modest losses to him in a card 
game called "preference." Koseltzov pulls out banknotes worth nearly three times the eight rubles his brother owes. As Volodya takes them, his brother barks, "How high did you play?" (154).

Here, Tolstoy, who himself had lost so heavily en route from Silestra to Crimea that he had had to hand over the deed to the main house at Yasnaya Polyana in which he had been born, endears Volodya to readers so his fate becomes theirs - a characteristic missing from the first sketch (except, perhaps, for the man who had lost a leg sitting on his hospital bed and plotting a return to the bastions as an artillery instructor), as well as the second, since, despite its profusion of characters, the reader is hard pressed to empathize with any. Not so Volodya, who, feeling his brother's query casts doubt on his honor, says nothing.

Vexed with himself, ashamed of having done anything that could give rise to such suspicions, and hurt at such offensive words from the brother he so loved, his impressionable nature suffered so keenly that he did not answer. Feeling that he could not suppress the sobs that were gathering in his throat he took the money without looking at it and returned to his comrades. (154)

The reader is drawn further into this character while, "[b]ump[ing] along" the Belbek road on the back of the trap, "the two brothers, their legs touching as they jostled along, sat in obstinate silence though they never ceased to think about each other (154). This physical proximity and mental distance after so long an absence prompts more pained thoughts regarding the loan in Volodya:

Why did he say that? ... Couldn't he have left it unsaid? Just as if he thought me a thief! And I believe he's still angry, so that we have gone apart for 
good. And yet how fine it would have been for us to be together in Sevastopol!

Two brothers, friends with one another, fighting the enemy side by side.” (154)

So begins Volodya's excursion into the aesthetic condition. The ending of these musings leads to, perhaps, the most moving moment in the entire series, as Volodya snapping to, blurts, "I say, have you ever been in a hand-to-hand fight?" The answer proves sobering: Michael, matter-of-factly, notes that, of the regiment's 2,000 dead, all were killed in the trenches, which was where he, too had been wounded. "War is not carried out at all the way you imagine, Volodya" (156).

The advisory serves a purpose in dispelling the young man's illusions, but the sentence packs a stronger punch, for Michael's use of the nickname for Vladimir (the younger Kozeltsov's given name) is the first such reference to the character, who, until now, has been "the brother," "the younger," "the younger brother, "or "the younger Kozoltsov." After the brief, heartfelt bout of humiliation and resentment, Volodya's hearing his brother call him by his nickname occasions a catharsis long awaited in this trilogy, lending readers an emotive entry into the rest of the sketch that makes it, arguably, a more powerful entreaty against war than all the previous broadsides, however eloquent and insightful. Finally, someone we care about lies at the heart of the story, and we become involved in his fate amid such incessant and merciless peril.

The pet name Volodya touched the younger brother. He longed to put matters right with the elder, who had no idea he had given offense.

"You are not angry with me, Misha?" he asked after a minute's pause [in turn, using his brother's pet name].

"Angry? What for?" 
“Oh, nothing... only because of what happened ... it's nothing.

"Not at all," answered the other, turning toward him and slapping him on the knee.

"Then forgive me if I have pained you, Misha! And the younger brother turned away to hide the tears that suddenly filled his eyes. (156) Assurance of his brother's love works like a tonic on the youth. As the two approach Sevastopol from the north, "Volodya looked without the slightest trepidation at the place that had so long been in his mind" (156). He maintains this attitude under questioning by the commissariat of Michael's regiment - a slovenly opportunist stationed on the North Side, across the Roadstead from the heart of town - whom they visit to establish where Michael must report. The war-weary officer is dumbfounded by the brothers' urgency to reach Sevastopol: ““Why do you do it, gentlemen? I don't understand it ... I'd be ready to walk to Petersburg on foot, I think, if they'd let me go. My God, I'm sick of this damned life. ... if you got any profit out of it - but no! Now would it be pleasant at your age to be crippled for life?"' (160) Answering for the two, Michael, who harbors no illusions, shows himself a man with lofty values and a deep sense of duty (he later proves himself to be one): “'Some want to make a profit and others serve for honor," he says "crossly" (160).

Only upon approaching the pontoon bridge leading across the Roadstead - a natural, deep, key-shaped harbor, at whose mouth the Russians had sunk their Black Sea Fleet to prevent the invaders from also shelling the city from the water - does Volodya begin to shed his illusions: He "was not exactly dispirited, but his heart was heavy" (161). The military's seductive spell, encouraged by the paternal attentions of the 
empire's figurehead and leader, had lured the impressionable youth into the fray, from which, he and the reader gradually realize, there is no escaping.

Fear and Foreboding

All he saw was so different from his past, still recent, experience ... the jolly, friendly voices of his comrades, the new uniform, the beloved Tsar he had been accustomed to see for the past seven years, and who at parting from them with tears in his eyes had called them his children - all he saw now was so little like his beautiful, radiant high-souled dreams. (161)

Those dreams further recede with each step the brothers take across the pontoon bridge as the silhouette of Sevastopol's skyline stands out against the flashes of bombs exploding in, above and beyond the city. Occasional Black Sea waves flow over the bridge, soaking Volodya's boots. A mounted officer accompanying a cart to the North Side for cannon cartridges recognizes Michael and informs him of an imminent attack on the Fifth Bastion, where their regiment is stationed. A comrade, Martsov, has had a leg blown off and lies in the hospital; Michael's lodgings and much of the city have been reduced to rubble; restaurants have been shuttered and the once gay boulevard music, silenced; even the last brothel had packed up the day before. Hearing such horrible news against so horrific a backdrop stuns the newcomer, who feels his once-gleaming uniform growing into a straitjacket:

Terrible fear suddenly overcame Volodya. He felt as if a ball or bombsplinter would come the next moment and hit him straight on the head. The damp darkness, all these sounds, especially the murmur of the splashing water - all seemed to tell him to go no farther, that no good awaited him here, that he would 
never again set foot on this side of the bay, that he should turn back at once and run somewhere as far as possible from this dreadful place of death. "But perhaps it is too late, it is already decided now," thought he, shuddering, partly at that thought and partly because the water had soaked through his boots and was making his feet wet.

He sighed deeply and moved a few steps away from his brother.

"O Lord! Shall I really be killed - just I? Lord, have mercy on me!" he whispered, and made the sign of the cross. (164)

The brothers' next destination reinforces the profound difference between this and the preceding sketch, which Wilson described as a "denunciation of the vanity and courage of popinjays like Kalugia (sic)" (116). In this regard, "Sevastopol in August 1855" marks a new tack in Tolstoy's writing about war. Whether it just happens to be on the way or is meant to make a human statement, the brothers' first stop in Sevastopol is the Ambulance Station. Unlike Prince Galtsin, Kalugin's fellow upper-cruster, the Kozeltsov brothers, under Michael's initiative, enter into the depths of the place, despite its being "permeated by a horribly disgusting hospital smell" - the same stench, undoubtedly, that had made Galtsin turn on his heel just in from the entrance (164).

When Michael asks one of the Sisters of Mercy attending the patients whether she knew the location of Martsov, who had lost a leg the day before, she asks back, "Is he a relation of yours?" "No, just a comrade," Koseltzov answers (165). These four words express more fellow-feeling than can be found in the entirety of "Sevastopol in May" except, perhaps, for the jocular repartee among opposing soldiers during the truce called to remove bodies from the killing field between their batteries. There is nothing jocular in 
this scene: Still in the hallway, Michael has to bring Volodya back to his senses as he stands "with raised eyebrows and a look of suffering on his face, unable to tear his eyes from the wounded.” “Come now!” Michael barks. Volodya follows but can't help looking over his shoulder and uttering, “O, my God! My God!” When the nurse assigned to accompany them - "a very pretty girl of about twenty whose pale, delicate, fair face looked from under her white cap with a peculiarly sweet helplessness" - asks whether his brother has been in Sevastopol long, and Michael informs her that Volodya has just arrived, she looks at the youth, and, breaking into tears, echoes his words: "My God! My God! When will it all end?” (165)

Discomfited, the nurse, upon entering the officer's ward, thoughtlessly asks Martsov, "Well, how are you?" to which the patient angrily answers, "In pain, of course!" On his jaundiced face, the brothers find "the expression of one who has clenched his teeth to prevent himself from screaming with pain. His sound leg with a stocking on showed from under the blanket and one could see the toes moving spasmodically" (165). The image of those toes and the comely nurse will reoccur to Volodya after the brothers, who had planned to go together to the elder's posting, decide to take no unnecessary chances but, instead, go their separate ways. Suggesting his batman, Nikolaev, accompany Volodya, Michael says he will come to find his brother the following day, but this, in fact, is the last the two will ever see of each other.

As Eikhenbaum notes, this parting introduces new devices of composition [including] a movement of two lines, a temporal parallelism. The two main characters are made brothers: this strengthens their position among the rest of the actors ... and likewise motivates the parallelism to 
which Tolstoy is naturally gravitating. Tolstoy does not need this parallelism for the development of a story ... but rather for the connection of scenes which remain essentially independent of one another (i.e. parallelism in its pure form).

In this fashion, we trace the brother's respective fates over the following 12 chapters - the first three (XII-XIV) with Volodya; the next three, Michael; the next six, Volodya; the next, the storming of the bastions viewed from Sevastopol's North Side; the next, the death of Michael; the next, the death of Volodya, and the final chapter (XXVII), the embittered Russian retreat upon the pontoon bridge crossing the Roadstead to safety on the North Side.

Walking through abandoned streets that sound with his footsteps, Volodya thinks of nothing as visions take over his mind, snuffing the bravura he had brought with him from Petersburg:

the pretty Sister of Mercy, Martsov's foot with the toes moving in the socks, the darkness, the bombs, and different images of death floated dimly before his imagination. His whole young impressionable soul was weighed down and crushed by a sense of loneliness and of the general indifference shown to his fate in these dangerous surroundings. "I shall be killed, I shall suffer, endure torments, and no one will shed a tear!" And all this instead of the heroic life abounding in energy and sympathy of which he had such glorious dreams. (167)

Left on his own in a city under siege, the youth's fear is such that he becomes a stranger in his own body: 
The bombs burst nearer and nearer. As they were crossing the bridge that led to the Korabelnaya, he saw a whistling something fall and disappear into the water near by (sic), lighting the purple waves to a flaming red for a second and then come splashing up again.

“Just look! Not quenched!" said Nikolaev in a hoarse voice.

"No," answered Volodya in an involuntarily high-pitched, plaintive tone which surprised him. (167)

Fear of His Own Fear

The self-alienation occasioned by menace, bewilderment, and fear reoccurs within an instant, as the following paragraphs describe his rapidly changing surroundings: the wounded on stretchers leaving the front and gabion-laden carts headed thereto, along with a cavalry regiment passing, one of whose officers, trailed by a Cossack, "reined up his horse, looked in his face, turned away, and rode on, touching his horse with the whip" (167). The effect of such odd behavior on Valodya is extreme, plunging him into another bout of dread and despair: "'Alone, alone! No one cares whether I live or not,' thought the lad, and felt inclined to cry in real earnest"; as he passes into a street of small demolished homes, continually lit up by the bombs, "a drunken, unkempt woman passing through a gate in stride with a sailor bumps up against Volodya and grumbles, 'pardon y'r exchensh offisher,"' leaving the youth further befuddled (167). His heart aches more and more, yet Volodya. too young to realize he'd bought into a glorious bill of goods, takes it out on himself:

He suddenly felt himself utterly and finally deserted. This sense of loneliness, face to face as it seemed to him with death, pressed like a heavy cold stone on his 
heart. He stopped in the middle of the square, glanced round to see if anyone was looking, seized his head and thought with horror: "O Lord, am I really a miserable coward ... when it's for my Fatherland, for the Tsar, for whom I used to long to die? Yes, I am a miserable, wretched being!" (168)

This conviction sticks with the youth as he reports to duty with the Fifth Light Artillery and so besets him that he proves barely able to answer the commander's query regarding the whereabouts of his duffel bag and belongings.

Poor Volodya was so oppressed by the thought that he was a coward, that he saw contempt for himself as a miserable craven in every look and every word. He felt as if the commander of the battery had already discerned his secret, and was chaffing him. He was abashed, and replied that his things were at the Grafskaya and that his brother had promised to send them the next day. (170) Sent to sleep below, his fears follow: first, that of finding his spirits so out of joint; second, that of a bomb plowing into the structure: 'If it does come,' he thought, 'it will first kill those upstairs and then me - anyway not me alone.' The thought comforted him a little and he was about to fall asleep" (171). Next, the possible fall of Sevastopol fills his mind, with the French rushing in and finding him fully unarmed: "The fear of real danger drove away the fanciful fear of the darkness. A saddle and a samovar were the only hard things in the room" (171). Scant defense, those. Again, though, Volodya, "amid the unceasing noise which made the panes rattle in the one window" continues to beat himself up over his justified sense of panic (172). "What a wretch I am - a coward, a despicable coward!' he thought again, and once more the oppressive feeling of contempt and even disgust for himself came over him" (171). 


\section{Fear Strikes Out}

The basement of the lodgings proves a symbolic setting for the spiritual nadir of Volodya's brief, passionate existence. His self-hatred seeking resolution, the youth, here, touches bottom, albeit not before another flight of fancy regarding his death - this time painted in lachrymose, not heroic, colors: "Now he seemed to see wounds and blood, then bombs and splinters flying into the room, then the pretty Sister of Mercy bandaging his wounds and crying over him as he lay dying, then his mother seeing him off in the little country town and praying fervently with tears in her eyes before the wonderworking icon - and again sleep seemed impossible"; his faith proves the youth's sole refuge, as "suddenly the thought of God Almighty, who can do everything and hears every prayer, came clearly into his mind" (172). As he kneels, makes the sign of the cross and prays as he had in childhood, Volodya starts to feel "an old, long-forgotten sense of comfort... 'If I must die, if I must cease to exist, then do it, Lord,' he thought, 'do it quickly, but if courage is needed and firmness, which I lack, grant them to me! Deliver me from the shame and disgrace which are more than I can bear, and teach me what I must do to fulfill Thy Will"' (172). The power of prayer proves a deus ex machina, as "[t]he frightened, cramped, childish soul suddenly matured, brightened, and became aware of new, bright, and broad horizons" (172). His dread assuaged, Volodya falls into a deep sleep, despite the menacing cacaphony around him. A more perfect closing out of the three chapters regarding the youth is hard to imagine.

A similarly sympathetic tone prevails as Tolstoy shifts to "[t]he elder Kolzetsov" clambering through the rubble of the city he once knew (which he finds "more melancholy. . . yet more vigorous") to report to duty at the Fifth Bastion (173). There, he 
proves repulsed by the finery he finds in the officer's casement: the screen door, the parquet floor, the bottles of pricey claret, and the hauteur of the new regimental commander, Batrishchev, a mere seven weeks on the job and, as evinced by the "tenruble cigar in his hand," fully enamored of its trappings (174). Kolzetsov struggles to understand why he feels "abashed in the presence of his former comrade ... [who used to] hobnob with us, wore one and the same dark cotton print shirt the whole week, ate rissoles and curd dumplings every day, never asking anyone to share them - but look at him now!" (174) Through this distasteful scene, a throwback to the smugness of the second sketch, Tolstoy takes occasion to observe the danger of leaders who do not feel they "can inspire respect by [their] own worth" and sets up readers for the next two chapters, in which the popular officer returns among the ranks (175).

Here we see a soldier's soldier, a Mensch; making us care for the character lures us further into the story. Before joining his fellow officers in the Defense Barracks, Kosletzov goes to greet the men he commands and learn where they are stationed. We are reminded of his first duty: visiting Martsov at the Ambulance Station. He passes from the breastwork of gabions past the trenches, stumbles over bombs and fragments - all lit up by cannon fire - until making his way into a bomb shelter crowded with soldiers. A sergeant-major welcomes him back "with a cheerful and friendly look" before inquiring of his health (176). Tolstoy notes: "It was easy to see that Koseltzov was liked by his company"; the buzz in the back of the bomb-proof runs, "Our old company commander has come back! Him that was wounded"; soldiers approach, and the drummer "greet[s] him" (177). After acknowledging one Obantchuk in jocular fashion - asking him "Still 
whole?" - Kozeltsov raises his voice to greet the men. The response is heartfelt and heartening: “'Wish your Honor health!' resounded through the casemate” (177).

There follows a brief exchange that reveals the inspiring commander that Kozeltsov is:

“'How are you getting on, lads?'

'Badly, your Honour. The French are getting the better of us. They give it us hot from behind their 'trenchments, but don't come out into the open.'

'Perhaps it will be my luck to see them coming out into the open, lads,' said Kozeltsov. 'It won't be the first time... you and I will give them a thrashing.'

'We'll do our best, your Honour,' several voices replied.

'Yes, he's really brave!' said a voice.

'Awfully brave!' said the drummer to another soldier, not loud, but so as to be heard, and as if justifying the commander's words to himself and proving that there was nothing boastful or unlikely in what he had said." (177)

The subsequent reception in the officers' caserne shows his fellow officers harbor sentiments similar to those of his charges: “'Ah, Koseltzov! Koseltzov! ... So you've come! That's good.... You're a brick.... How's your wound?' It was evident that he was liked here also and that his return gave pleasure" (177). Nevertheless, a sense of desperation hangs in the air. As Michael drinks a couple of vodkas and sits down to a card game among colleagues, a dispute breaks out involving a major due eight rubles from the banker, who is broke because a heavily sweating red-faced officer owes 150 rubles that he promises to pay "to-morrow." None knows tomorrow will not come, but sensing as much, everyone kicks that prospect down the road. Tolstoy hasten[s] to drop 
the curtain on the scene, grimly noting: Tomorrow or today, perhaps, each of these men will cheerfully and proudly go to face death, and die steadfastly and calmly; but the only relief in these inhuman conditions, horrible even to the coldest imagination and from which there is no hope of escape, is to forget and suppress consciousness" (179). The die is cast. The men are doomed, and there is no point in fearing what is predestined.

The scene foreshadows Volodya's fate after a courier arrives with orders from the Chief of Artillery that an officer and some men be sent to a mortar-battery. Pointing at him, Tchernovitski, the senior officer whom no one especially likes, volunteers the newcomer for the assignment, saying, "There's your man - he's not been anywhere yet" (186). The commander says nothing. While the youth's valor is evident, nor can his fear be disguised: “'Yes, I should like to go,' said Volodya, feeling a cold sweat break out on his back and neck" (186). After a fair-minded captain suggests choosing lots, they do so. Volodya goes first, drawing a paper on which it reads, "Go."

“"It's I,' he said with a sigh," prompting the commander to put a positive spin on the ill-fated draw; he wishes the youth Godspeed and bucks him up by noting "'You'll get your baptism of fire at once' ... [while] looking at the ensign's perturbed face with a kindly smile" (187). Assigned to accompany Volodya as gun-sergeant is a cadet named Vlang, who has cared for the fresh-faced newcomer hand and foot since he arrived at the caserne and has developed a clear affection for him - largely because Volodya "treated him as an officer and did not order him around as if he were a boy" (181). Again, we appreciate the Kozeltsov family traits of decency, humility and compassion. For his part, Volodya, gathering his gear and boning up on the trajectory tables of the mortars he will be launching, 
noticed to his surprise and joy that his fear of the danger and even greater fear that he was a coward, though it still troubled him a little, was far from what it had been the night before. This was partly the effect of daylight and activity but was chiefly due to the fact that fear, like every strong feeling, cannot long continue with the same intensity. In short he had had time to live through the worst of it. (187)

This resurrected spirit animates Volodya as he hails his men - "Good day, lads!" and leads them up the hill toward the Malakov Redoubt. The greeting, perhaps, implies that his own days as a lad are behind him. He notices Vlang constantly ducking and darting as if all the munitions coming their way were directed solely at him. Several soldiers follow suit, and Volodya sees fear on many faces. Rather than scaring him, though, the sight of their generalized Angst "emboldened . . . and completely comforted him" (188): "So here I am, too, on the Malakov mound, which I fancied a thousand times more terrible. And I get along without bowing to the balls, and am even much less frightened than the others. So I am no coward," he thought with pleasure, and even with a certain self-complacent rapture (188). This zeal is, shortly, dampened by the grisly sight he chances upon atop the Kornilov Battery, where he goes to report to the commander. Four sailors stand by the breastwork swinging the corpse of a dead comrade back and forth - each holding either a hand or a bootless foot - as they try to give the bloodied body the heave-ho over the structure but fail to clear its edge. "Volodya felt stunned for a moment when he saw the body bump on the top of the breastwork and then roll down into the ditch, but luckily for him, the commander of the bastion met him just then and 
gave him orders and a guide to show him the way to the battery and to the bomb-proof assigned to his men" (188).

Analyzing the incident and its effect on Volodya, Gierik juxtaposes the human and militarily perspectives:

The sight of a man as a dead body, a thing that is just thrown aside because it's in the way, draws Volodya out of his fearlessness and self-satisfaction and back to reality. Shortly, though, he is relieved of his experience by military institutionality, within whose sphere of activity everything here occurs, and the truth he has witnessed has no lasting effect. (246)

\section{Fearless Toward One's Fate}

The scene prepares readers for a later image that, for all purposes, marks the grim ending to both this and all three Sevastopol sketches. In the meantime, Volodya has shed his fears despite being "twenty times within a hair's breadth of death" while following a "gigantic gunner" appointed to assist him in repairing a mortar platform (188). His transformation from a transfixed greenhorn is complete as Volodya retires for the night, joining his men in the stuffy bomb-proof, where his drinking tea and joking with the non-commissioned officers shows the soldiers that "the gentleman g[ives] himself no airs" and makes them relax (189). As the others arrange themselves for sleep, Volodya, duty-called, decides to step outside, despite the continuous barrage. As he moves through the cramped shelter, soldiers call out, "Draw in your legs!" to give him room - another sign of the respect in which they hold him (192). For three hours, he sits at the entrance to the bomb-proof, "finding a kind of pleasure in tempting fate and 
watching the flying bombs. By the end of the evening, he knew how many guns were firing, from which positions and where their shots fell" (193).

When they set out the next morning to fire the mortars from the Malikov Redoubt, the courage Volodya displayed while leading his dodging, darting charges the previous evening has infected them, too, and "not a trace of the fear noticeable the day before remained among the men as soon as they were actively engaged" (195). Vlang and one other soldier still jump about, but the rest appear to have settled in. "Volodya was in ecstasies, the thought of danger never entered his head. Joy at fulfilling his duty, at finding that not only was he no coward but that he was even quite brave, the sense of commanding and being in the presence of twenty men who were he knew watching him with curiosity made him quite valiant" (195). Still prone to the aesthetic condition, though, Volodya grows "even vain of his courage and show[s] off before the soldiers, climbing out onto the banquette and unfastening his cloak on purpose to be more conspicuous" (195). As much cheerleader as officer, he displays a bravura that catches the eye of his commander, who "could not help admiring this handsome lad, with his coat unbuttoned showing a red shirt fitting close to his delicate white neck, who with flushed face and shining eyes clapped his hands, gave the order, 'One - two!' in ringing tones, and ran gaily onto the heavy breastwork to see where his bombs were falling" (195). Volodya's two-day inner bout with, and consequent conquest of, fear reaps scant returns, as the chapter closes with announcement of the French storming of the Redoubt, along with the Second, Third and Fifth Bastions (at the latter of which Michael is stationed). The perspective of Sevastopol from the North Side, which makes up the following chapter, reveals the Russian guns on the Redoubt barely sputtering while French shells 
rain down upon it; the chapter ends with the French flag flying above the fortification. This distant view prepares readers for the worst, which is quick in coming, as the narrator zooms in on the action at, first, the Fifth Bastion, and, next, the Malakov Redoubt (195).

Whereas Volodya has had to conquer "his fear of the danger and even greater fear that he was a coward" (top of page 71, above), Michael, who overcame both fears long before, hastens not to be considered craven at a crucial juncture for which he is poorly prepared. Despite having lost his last three rubles the evening before, Kozeltsov had continued playing cards, winning at first, then losing it all - even the four gold pieces he had sewn into his pants' cuff - before falling into a "heavy, unhealthy, and deep sleep" (197). Startled awake by "a desperate cry ... repeated by many voices," he blurts, "The alarm!" but thinks it a hoax, even after a colleague tells him they are under attack (197). As a fellow officer, the color gone from his face, runs past and out of the barracks, Michael's sense of duty makes him hop to: "The thought that they might take him for a coward who did not wish to be with his company at a critical moment upset him terribly, and he rushed full speed to join it" (198).

Outside, he hears an officer yell that the Schwartz Redoubt has fallen and "All is lost!" Angered, as he had been when the commissariat on the North Side had questioned his purpose in returning to fight in Sevastopol, Kozeltsov answers "Nonsense," and, drawing a cutlass, yells out, "Forward, lads! Hurrah!" It will prove his last command. After leading a group of 50 men along a protective traverse, he enters into an open space, where "[t]he bullets fell like hailstones" including two that strike him "but where or what they had done - bruised him or wounded him - he had no time to determine" (198). Noting soldiers dressed in blue and red swarming everywhere, shouting in foreign 
tongues, Kozeltsov feels death to be immanent, which only makes him braver. He runs after the retreating French, but other soldiers pass him, his vision grows blurry and his chest starts hurting with what will prove a mortal wound (198-99).

This becomes evident in roundabout fashion as a heavily whiskered doctor examines him, covers him up, wipes his hands on his shirt, moves on to the next patient and sends a red-bearded, cross-wielding priest over to Kozeltsov, who asks whether he is dying. Without answering, the priest prays for Michael's soul and holds the cross to his lips. Having reflected on his performance at the Fifth Bastion and decided he had done his duty as best he could and had no cause to rebuke himself, he takes the cross, kisses it, and weeps. "Death did not frighten Kozeltsov," the narrator notes (198). His final thoughts still revolving around the battle, he asks whether the French had been repelled and is assured they had, on all fronts. The cleric's effort to solace the soldier by invoking the aesthetic condition right to the edge of the grave flies in the face of truth, as the French flag is already flying above the Malakov Redoubt; his words, though, serve his purpose, and Kozeltsov, "conscious of having performed a heroic deed," thanks God and thinks immediately of his brother: "God grant him as good a fate” (199).

This wish shall go unfulfilled. Volodya, who has not only shed the fear that once possessed him but grown brazen in the face of danger, orders grapeshot fired at an oncoming swarm of French soldiers, whose bayonets glisten in the sun. Heedless of the peril of being exposed to enemy fire, he shuttles between the mortars and proves unaware of a score of Frenchmen approaching on the left flank. One fires at him "point-blank" as the breastwork is overrun. The timorous Vlang manages to clobber another Frenchman over the head with the linstock used for firing the mortars, gaining time to jump into a 
trench full of comrades shooting at the French. From there he yells for Volodya to seek cover: "Why are you stopping? Run!" Vlang climbs out briefly to see "what his adored ensign was doing," setting up, perhaps, the most piteous passage of the Sevastopol Sketches: "Something in a cloak lay prostrate where Volodya had stood" (201).

This impersonal description of the dead youth - whom we, through Tolstoy's heartfelt artistry, had come to care for deeply - leaves us wordless. Its chilling effect ranks with that of the final scene of $A$ Farewell to Arms. The passage proves as harsh an indictment of the senselessness of war as the mid-August 2016 AP photo of five-year-old Omran Dagneesh, caked in dark, dried blood and dust, seated in an orange chair after being pulled from the rubble of a building bombed in Aleppo. "Volodya dies senselessly and miserably," Eikhenbaum observes (117). The "something" reference repeats the leitmotif first sounded in Baron Pesth's hand-to-hand combat scene, in which "someone seized a bayonet and stuck it into something soft" (124). Despite the emotional vacuum left in the wake of Volodya's death, experienced, perhaps, as a negative catharsis, not every critic found Tolstoy's final sketch worthy of its fellows. The writer of one unsigned review of "Sevastopol in August" found the piece also unworthy of its name. Not only did he consider the sketch weaker than the other two, but he also claimed that Tolstoy, himself, had, as well, since it marked the last of a string of military stories dating from the author's time in the Caucasus. "[T]he complete embodiment of that ignorance and inexperience which a man who has seen nothing of the world should have," Volodya, in fact, mirrors the youthful protagonists of those previous tales, the critic writes in a twopointed panning of the sketch. The second prong commends the writer for his detailed descriptions but berates him because 
the general picture has vanished, is lost; there is no general picture. At Sebastopol ... the author has again thought of riveting us to his observations on the psychological phenomena of the young man's soul! Is it possible to make such a blunder? The events taking place are remarkable, while we sit with the young man in a corner and look not at the general picture of the assault, the battle and the retreat; no, we see how the feelings of fear, pride and despairing bravery switch in the young man's soul! The author should have called his story "EnsignVolodya Kozeltsov" and not "Sebastopol in August" and then Volodya Kozeltsov would have been one more wonderful portrait from the hand of the talented author; we would have been satisfied with him while now we are cross at him for distracting our attention from the terrible and shattering picture. (Knowles 58)

The critic may be forgiven his retro-riveted demand that Tolstoy stick to the canon; in light of historical evidence, however, his viewpoint appears old-hat. The technique of sitting "with [a] young man in a corner of the scene" has found modernist emulators the world round: the authors of those books that most intimately portray the human experience of war - especially, the instinctive, initial fear soldiers must face and conquer - from Eric Maria Remarque's Im Westen Nichts Neues (All Quiet on the Western Front) to such classic American novels, noted by Gierigk, as John Dos Passos's Three Soldiers, Ernest Hemingway's A Farewell to Arms and For Whom the Bell Tolls, and Norman Mailer's The Naked and the Dead. This particular sketch, "Sevastopol in August 18555," also most closely serves as the prototype of the first and, arguably, foremost work of which this can be said: Stephen Crane's The Red Badge of Courage. 


\section{CHAPTER III}

\section{FROM A FOURTH BASTION OF HIS OWN INVENTION}

\section{TO THE RED BADGE OF COURAGE}

\section{The Last Degree of Otherness}

Crane employed, and may have adopted from the first Sevastopol sketch, an anonymous identification of character throughout The Red Badge of Courage, perhaps attempting, through different means, to represent "Everyman." Instead of Tolstoy's ubiquitous "you" in "Sevastopol in December 1854" and brief descriptions of characters who scurry into and out of the narrative, once a character has made an appearance, the definite article combined with a single personal trait is the extent of his identification in The Red Badge. Hence, we meet "the youth," "the tall soldier," the loud soldier," "the tattered soldier," and "the sarcastic man." None are ever named by the narrator, but by their fellows, alone. "What is uppermost in the representation is the ordinariness of the participants," notes Cox, who calls "the informal, unschooled ordinariness of these soldiers ... the very stamp of Crane's realism" (334). This is a far cry from the vainglorious "upper-crusters" crowding the pages of "Sevastopol in May," if not so far from the wounded hospital patient we encounter in "Sevastopol in December" or either of the Kozeltsov brothers, whose fates dominate the trilogy's ending.

Similarly, Crane rejects the overview approach - historical or otherwise - to telling his tale, which a less original writer might have derived from "the finest realistic narrative to come directly from the Civil War," the Personal Memoirs of U.S. Grant, recently published by Mark Twain in 1885; the two-tome 
best-seller could not have escaped Crane's notice. No book should have appealed to him more, considering his pride in the military exploits of his Revolutionary ancestors, his having from early childhood played games of tactics and not just fighting, his rise as a school-boy cadet to the rank of captain, and his youthful hopes of going to West Point But nothing in the record suggests that he responded in any way at all to a book which was everything that The Red Badge wasn't.

\section{(Levenson 191)}

Crane, rather, adhered to the tradition that Stendhal had established and Tolstoy had advanced, as discussed in Chapter I of this thesis. Nowhere is this better noted than in Cox's description of the work, which provides a thorough accounting of everything the novel lacks:

Not only are there no actual place names ...; there are no fictive place names. If there is topography in the form of a small river or an open field or a forest, it remains utterly generalized. There is exactly one mention of Richmond and Washington. There is no Grant or Lee or Hooker or Jackson or Meade or A.P. Hill. There is not even a North or South. Even the terms Yankee and Rebel appear only once or twice as yank and reb. There is no fight for the union or against slavery. There is not a mention of Abraham Lincoln or Jefferson Davis. There is not a hint of states' rights or the protective tariff. ... there is no real sense of the technology of war....[W]e get no particular or detailed identity of any of the machinery. We get no mention of supply depots or howitzers. Finally, there is no romance in the book. (332) 
Gierick draws a similar parallel between Tolstoy's sketches and the memoir penned by another of the world's great generals: Julius Caesar's Gallic Wars, which, at the outset, takes a political-geographic perspective: "'Gallia est omnis divisa in partes tres...'('Gaul is divided into three main parts ...'). In Tolstoy's Sevastopol-cycle, one will search in vain for an analogous statement.... At the uttermost extreme, one may say: With Tolstoy, there is no field-marshal" (243).

Gierick deems these two perspectives "the state of war" (as viewed broadly and from above) and "the action of war" (as experienced at the front or in the trenches). Given Tolstoy's occasional citing of commanders, such as Kornilov and Todleben, and actual sites, such as the Fourth and Fifth bastions, Sevastopol's main boulevard and Morskaya Street, Crane ventures further into creating a setting that could pass as "Any War Theater." Should this indistinctiveness serve any purpose, it is surely that of focusing on, and magnifying. the subject he had studied all his life, the little man - in this case, the foot soldier.

Tolstoy's Sevastopol Sketches describe action in the Crimean War at three junctures over a period of nine months, providing a natural separation of the sections of Chapter II of this thesis. Since, apart from occasional flashbacks, the action in The Red Badge occurs within a matter of days, no such clear-cut division is provided, so the same thematic treatment accorded the second two Sevastopol sketches shall be applied here. In terms of the topic of fear, the book has a balanced beginning, middle, and end. The opening part of this chapter, then, will discuss the aesthetic condition that led protagonist Henry Fleming to join the war effort in which he is embroiled; the premonitions of overpowering fear that beset him from the start, making him fear that subsequent fear 
might cause him to flee; and the circumstances under which he succumbs to that fear and, in fact, flees. The second section will explore Henry's efforts to face down the shame of his fear and flight, first in a penitential phase, during which he desperately seeks to rationalize his behavior and, through Nature, comes to accept it; and, secondly, in a surreptitious phase, in which he seeks to conceal his desertion and must deal with the now-greater fear of its being detected. The third section will trace Henry's path to rectifying his desertion by subtly reincorporating himself into his unit and - now seemingly fearless - leading it into a battle in which the other side concedes (bringing the drama full circle) and realizing himself as a young man now in control of his emotions albeit, harboring a secret.

Presentiments than "a youthful private" enters the picture as he retires to his tent to tend to "some new thoughts that had lately come to him" (2). These ruminations will captivate both the soldier's and reader's minds for most of the following 156 pages, as we enter the action in both medius res and medius menses - the middle of the action and the innermost recesses of the protagonist's mind: "So they were at last going to fight. On the morrow, perhaps, there would be a battle, and he would be in it" (2). For all dramatic purposes, both narrator and protagonist here throw down the gauntlet.

From flashbacks, we learn that repeated instances of the aesthetic condition had lured "the youth" into the conflict: "He had, of course, dreamed of battles all his life.... In visions he had seen himself in many struggles ... [and] imagined peoples secure in the shadow of his eagle-eyed prowess" (11). Similarly, when rumors of troop mobilizations spread, "there seemed to be much glory in them," throwing him back on books he had 
read of "marches, sieges, conflicts. [H]e had longed to see it all. His busy mind had drawn for him large pictures extravagant in color, lurid with breathless deeds" (12). Fractioning Fear

Even the local church helps cast the spell, as its constant clanging to report Union triumphs makes the youth "shiver in a prolonged ecstasy of excitement" the night before he enlists (12). Although these fantasies are juxtaposed to his mother's sober-minded comments as she unceremoniously sees him off over potato pairings and tears, there will be no raining on Henry's parade: admiring townsfolk, "the smiles of girls," and the encouragement of old men make him "feel within him the strength to do mighty deeds of arms" (15). Yet, going from fanfare to warfare is a mighty leap for a youth, and a sober tone on the brink of battle returns, as it had with Volodya in that shabby Crimean poststation where he runs into his elder brother, Michael, who suggests they head without delay for Sevastopol: “"Now at once, straight to Sevastopol ... into that hell ... terrible! ...' In fact, only now ... did he clearly realize the danger he had been seeking, and he grew confused and frightened at the mere thought of the nearness of that danger (152).

Fed by contemplation of impending combat, Henry's escalating fear also echoes that Tolstoy, himself, had felt, as described in a letter to his brother on the eve of what was supposed to be the June 9, 1854, Russian invasion of Silestra: "As you know, Nikolai, the period that precedes an engagement is the most unpleasant - it's the only period when you have the time to be afraid, and fear is one of the most unpleasant feelings" (Troyat 109). In Tolstoy's case, the invasion was called off, but not in Henry's. Lying on his bunk, the youth addresses that fear, which has made the enemy into a monolithic fighting force instead of a group of men and youths - human beings, in short 
- such as he and his comrades: "He perceived now that it did not greatly matter what kind of soldiers he was going to fight, so long as they fought, which fact no one disputed. There was a more serious problem. ... He tried to mathematically prove to himself that he would not run from a battle" (16).

Reverting to formulae to measure the probability of his succumbing to fear reappears throughout the novel, starting on the very next page, where Henry realizes that nothing in his past experience has prepared him for battle: "He was an unknown quantity" (17). His efforts mathematically to measure his merit as a soldier become a leitmotif: "For days he made ceaseless calculations . . . all wondrously unsatisfactory. ... He could not sit still and with a mental slate and pencil and derive an answer" (21). Despite all the reckoning and reasoning, he fails to dispel his fear. As the moment of truth approaches, he comes to view the aesthetic condition that had seized him earlier as a form of self-deception, exactly as had Volodya: "He recalled his visions of broken-bladed glory, but in the shadow of the impending tumult he suspected them to be impossible pictures" (17). Stated in more prosaic terms, and with "Henry Fleming" at the close of the passage, Eikhenbaum's (Stendhal-inspired) observation about "Sevastopol in August 1855 " proves equally apt for The Red Badge: "We are also familiar with the psychology of a novice who goes off to war and finds nothing of his dreams in it. Such is Volodya Kozeltsov"(114).

Once the prospect of turning tail has wormed its way into his mind, Henry finds succor when "the tall soldier," Jim Conklin, acknowledges "in a tolerant way" that new recruits sometimes run when they first face fire. Jim's confession that he, himself, would probably run if things grew "too hot ... and a whole lot of boys started and run" is a way 
of throwing a brotherly arm around Henry's shoulder and should temper Henry's later obsessive condemnation of his flight. No memory of these words, however, appears to offer Henry solace, although witnessing the death of Jim, who had stood his ground, fought, and been mortally wounded, will prove a milestone in Henry's spiritual resurrection. Also evident at this juncture is a variation on the parallel plot structure Eikhenbaum points out in "Sevastopol in August," in which the two Kozeltzov brothers meet by coincidence en route to Sevastopol, travel together, separate to join their respective battery units, alternately reappear throughout the next ten chapters, then die separately in the same final, futile defense against the French. The obvious parallel is that between Jim Conklin and Henry, in terms of the former's advising and comforting the latter, as does Michael Koseltsov, upon gently disabusing Volodya of his Petersburg-bred preconceptions about war. A better analogy in terms of the characters' parallel fortunes, however, would be that between Henry and "the loud soldier," whom we come to know as Wilson; as do the Kozeltsov brothers, these two (due to Henry's desertion) become separated yet share the same ultimate fate (antithetical to that of the Kozeltsovs', theirs is the triumphant one of serving as standard bearers in a victorious campaign). More important to this thesis, Henry and Wilson are united in fear. Each suffers an initial bout of existential Angst, yet manages to overcome it and grow as a person and soldier. Jim Conklin, in comparison, seems to have been born to face down fire; his death, juxtaposed to the survival and triumph of the two "fresh fish" who dreaded the prospect of combat, adds yet another irony to this irony-laden tale (16).

Anticipating his first battle, Henry feels thankful for "these words of his comrade," which help him see, if only momentarily, that he is no different from his 
uninitiated peers. "He had feared that all of the untried men possessed a great and correct confidence. He now was in a measure reassured" (17). This reassurance won't last; in fact the isolation and impotence Henry feels in relation to others - friend or foe - will become another leitmotif throughout the novel, extending to enemy soldiers and the specter of war, itself. This phenomenon is part and parcel of the perspective provided by the "cylinder of vision" narrative technique, in which "the central concern ... is the literal and figurative dimensions of [Henry's] perception" (Nagel 294). The "unknown quantity" Henry carries inside keeps him guessing, if not at its amount then at its nature (17). He will never find the square root of his fear because not formulae but feelings and the degree to which Henry transfers these onto both others and the natural world determine the ever-shifting sum, which, depending less on facts than Henry's mood, defy the principles of mathematics. In short, no rational answer to Henry's conundrum shall be found:

Sometimes he thought [his peers] all heroes. In fact, he usually admitted in secret the superior development of the higher qualities in others. He could conceive of men going very insignificantly about the world bearing a load of courage unseen, and although he had known many of his comrades through boyhood, he began to fear that his judgment of them had been blind. Then, in other moments he flouted these theories, and assured himself that his fellows were all privately wondering and quaking (21).

This train of thought - or, perhaps, these colliding trains of thought, since they run in different directions on the same rail - exemplifies one of the dynamics that account for much of the grip this book has on readers. As Cox succinctly observes, "His thoughts 
always at war with each other, [Henry] is himself embattled; at the same time he is in a battle" (334). The former conflict continues as the regiment marches to the front with Henry "engaged with his own eternal debate ... [and] "separated from the others" (25). The sense of separation is, of course, occasioned by the content of that unending debate, which may be considered a variation on Hamlet's "to be or not to be" dilemma. Nature, alone, offers consolation as Henry lies down to sleep: "The liquid stillness of the night enveloping him made him feel vast pity for himself. There was a caress in the soft winds; and the whole mood of the darkness, he thought, was one of sympathy for himself in his distress" (25).

As in Tolstoy's Sevastopol, Nature's balm acts as counterpart to man's infernal machinations throughout The Red Badge, and, later, even provides the turning point of the tale when Henry comes to acknowledge that his reaction to the second wave of the Rebel attack might, in fact, have been in perfect keeping with its laws. All the bombast that brought him to war now far behind him, Henry, understandably, yearns for home, where "he had often cursed the brindle cow and her mates, and had sometimes flung milking stools. But, from his present point of view, there was a halo of happiness about each of their heads, and he would have sacrificed all the brass buttons on the continent to have been able to return to them" (25-6).

The soldier's version of buyer's remorse is the flipside of the aesthetic condition; it emerges in the gravely sobering realization that one's life is on the line amid implacable menace. Similarly, Volodya's aestheticizing his recent past in Petersburg, "the jolly, friendly voices of his comrades, the new uniform, the beloved Tsar ... who at parting from them with tears in his eyes had called them his children," occurs upon his 
first planting foot in Sevastopol, where "all he saw ... was so little like his beautiful, radiant, high-souled dreams (161).

Wilson temporarily shakes Henry out of his funk, but the youth's efforts to transfer his fears onto his seemingly confident comrade backfire, making the latter walk off, leaving Henry to sink deeper into isolation and despair: "No one seemed to be wrestling with such a terrific personal problem. He was a mental outcast" (28). At this point, Henry's phobia assumes the hallucinatory features that become a hallmark of the book, employed to describe everything from marching columns, "moving monsters wending with many feet ... serpents crawling from the cavern of the night" (23); to clouds of smoke, "observant phantoms" (37); to the enemy, "the composite monster" (41) prowling behind "the red eyelike gleam of hostile camp-fires set in the low brows of distant hills" (9); to war, itself, "the red animal ... the blood-swollen god" (33-4)); and, finally, to the mortal terror Henry carries within: "In the darkness he saw visions of a thousand-tongued fear that would babble at his back and cause him to flee, while others were going coolly about their country's business. He admitted that he would not be able to cope with this monster" (28).

His seeing himself as part of a "blue demonstration" and within "a moving box" reflects a loss of self-determination, as if he were caught in the lockstep of those impressed into a hideous venture. His feeling trapped heightens Henry's fear and urgent need for resolution. Reverting to the aesthetic condition provides the comfort he seeks, while conveniently serving the narrator in foreshadowing Henry's subsequent inner transformation: "The youth had been taught that a man became another thing in battle. He saw his salvation in such a change.... He wished to return to camp ... or else to go into a 
battle and discover that he had been a fool in his doubts, and was, in truth, a man of traditional courage. The strain of present circumstances he felt to be intolerable (35). That tension, deriving from the Angst-induced chaos reigning in his mind, makes even the tomb seem attractive, since there the internal tumult shall find resolve. "Regarding death thus "out of the corner of his eye," he sees it, simply, as "rest" and wonders why he had made such a big deal out of the prospect of his own - the more so for the solace and compassion sure to await him, since "he would go to some place where he would be understood. ... He must look to the grave for comprehension" (36-7).

What, to his surprise, he finds instead is a fellow "fresh fish" less intent on keeping his fears to himself. His volume belying his valor, the "loud soldier...quite pale and his girlish lip...trembling" approaches Henry the night before their first battle (which only Henry, of the two, will flee) to share a premonition of his own impending death (37). Despite all his previous swagger and seeming self-assurance, Wilson entrusts the youth with letters and keepsakes to be sent to his kin in the event Wilson should be killed. This act astonishes Henry, who readily accepts the "little packet done up in a yellow envelope" (37). His later recalling the handoff will prove a major boon to his regaining his morale after Wilson - now referred to as "the friend," or, more frequently "his (Henry's) friend" - discretely reincorporates the wayward youth back into the ranks (96). Henry holds the incident in reserve lest he have to draw it, like a psychic dagger, should the one-time loudmouth ever revert to form and confront Henry on his flight.

Just before this initial exchange, another factor likely to fuel a soldier's fear enters the picture: a lack of confidence in the self-important generals who keep the men constantly, purposelessly, moving about. In an odd state of mind during yet another 
endless march, "[a]bsurd ideas took hold upon [Henry] who decides "that the generals did not know what they were about. ... The generals were stupids" (33). In "Sevastopol in May," Tolstoy provides an ad nauseam exposition of just how stupid officers can be; yet, lacking the foot soldier's (or serf's) viewpoint, we must rely on the narrator, himself, to pass judgement. Crane's "cylinder of vision" technique replaces the narrator's perspective with that of the private. Henry, while still in camp, already feels an impulse to "break from the ranks and harangue his comrades" so they won't all be killed like swine led to slaughter (33). He is not alone in "denot[ing] a lack of purpose on the part of the generals": The loud soldier echoes Henry in berating the brass for leading foot soldiers on forays as countless as they are pointless: "It ain't right," he tells the tall soldier early on in the tale. "I tell you if anybody with any sense was a-runnin' this army it -" (35). Subsequent evidence within the novel confirms this assessment, such as a third soldier encountered "amid a blood-stained crowd streaming to the rear [who] was swearing that he had been shot in the arm through the commanding general's mismanagement of the army," to which one may, presumably, also attribute the massive retreat (63).

The historical record in no way varies in this regard, if Crane's work was, in fact, based to some degree on the 1863 Battle of Chancellorsville - the conflict with which he was most familiar, thanks to the time he, as a youth, spent among the "Orange Blossoms," and to which critics most often point in an effort to factualize this fictional work. The prospect of poor leadership should also be considered upon assessing a young recruit's decision to abandon a battle - especially after witnessing, en route to the front, a rearward "stampede exert[ing] a floodlike force that seemed able to drag sticks and 
stones and men from the ground (41). This and a handful of similarly radical terms describing an entire regiment's turning tail provide a compassionate context to Henry's dilemma once he follows suit - a context much overlooked (by no one more than Henry, himself) upon considering the youth's moral plight. Each of those scores of high-stepping defectors must also face the inner battle and outward shame that Henry, shortly, shall, and their fleet-footed desertion right beneath Henry's nose before he has even fired a shot serves to set his own fear-induced flight and its moral ramifications within a broader framework: that of Everyman. So does Crane hint at, if not outright display, the universality of the youth's struggle.

Their regiment now moved up to the front, Henry and his comrades anticipate a second wave of the enemy attack that had sent the scores of soldiers he had just witnessed scampering rearward. Curiously, Henry's thoughts turn to a springtime circus parade back home, focusing on an elderly man who would sit on a cracker box in front of a shop and act as if looked down on such civic spectacles. Could the man's appearing "in middle prominence" reveal Henry's waxing distrust of the aesthetic condition that had made him enlist? (42) Before he has time to unravel that knot, there approaches "a brown swarm of running men who were giving shrill yells" (42). "At the sight of them," the narrator notes, "the youth was startled by a thought that perhaps his gun was not loaded" (43).

Undoubtedly, it was less the sight than the sound of the foes that left Henry "trying to rally his faltering intellect so that he might recollect the moment when he loaded it," in which effort he fails (43). The infamous "Rebel Yell" - which one Federal soldier called "the ugliest [screams] any mortal ever heard," another deemed "barbarous howling," and a third said "made the hair stand up on my head" - played a special role at 
Chancellorsville, as it had when first employed - also under Gen. Stonewall Jackson - at the 1861 Battle of Manassas (Robertson 168). Crane, shortly after publication of The Red Badge, noted in a letter to the editor of Leslie's Weekly in which he calls for literary realism and fulsomely praises Tolstoy, that "the nearer a writer gets to life the greater he becomes as an artist" (Gierick 265). True to this spirit, Crane's principal primary sources in writing The Red Badge were, again, the veterans whom he had encountered as a youth in the park across the street from the Methodist Church in which his father preached, and whose nickname, the Orange Blossoms, referred to the eponymous county from which Crane hailed. Nearly six dozen New York regiments saw action at Chancellorsville. One of the Orange Blossoms' officers might have been the "New York captain [who] recalled, 'the heavens ...filled with hot-breathed, shrieking demons"” upon recounting the Rebel Yell (Robertson 153). The impression that blood-curdling Southern salute might have made on a teenage country boy in his baptism by fire must have been exponentially more frightening than that made on a battle-hardened captain. Hence, we see Henry sweating profusely and "turning swiftly to make sure the rear was unmolested" [perhaps, in the event he seeks to flee] as he stands caught between a general's savage insistence that the men "hold 'em back!" and an impending enemy assault (43).

As action is the surest tonic to demoralizing trepidation, the sight of the "foeswarming field in front of him" makes Henry "instantly cease to debate the question of his piece being loaded" (43). Every futile intellectual exercise and mathematical equation spinning in his head suddenly gives way to action - urgent action - as he, perceiving mortal danger, shoots his rifle wildly, then, getting a grip on himself, comes to work it as an extension of body and soul. So does Henry transcend his egotistical fear and become, 
as does every soldier worthy of the name, "not a man but a member ... [part of] a common personality ... dominated by a single desire" and no more able to flee "than a little finger can commit a revolution from a hand" (44). Once in action, his fear and sense of isolation vanish, as had Volodya's upon mounting the Malakov breastworks to assure the shot from his duel mortars was finding its mark (Tolstoy 195). This sense of belonging, which contrasts sharply with the feelings of isolation that beset him before, only expands under fire, as Henry develops "a consciousness always of the presence of his comrades. ... He felt the battle-brotherhood more potent even than the cause for which they were fighting. It was a mysterious fraternity born of the smoke and danger of death" (44).

Evidence of such danger now surrounds the youth, who finds "under foot ... a few ghastly forms motionless [that] looked to be dumped out upon the ground from the sky" (47). As Henry comes to his senses, the narrator juxtaposes Nature's prevalence and soothing effect in terms, again, reminiscent of Tolstoy: "As he gazed about him the youth felt a flash of astonishment at the blue, pure sky and the sun gleaming on the trees and fields. It was surprising that Nature had gone tranquilly on with her golden process in the midst of so much devilment" (48).

The surprise trial has been passed, as had Volodya's, after he and his comrades drew straws for the chance assignment of leading a cowering crew up the Malakhov Redoubt: "So here I am too on the Malakhov mound, which I fancied a thousand times more terrible. And I get along without bowing to the balls, and am even much less frightened than the others. So I am no coward," he thought with pleasure, and even with a certain self-complacent rapture (188). Henry finds himself equally enthralled: "He went 
into an ecstasy of self-satisfaction. He had the most delightful sensations of his life. Standing as if apart from himself, he viewed the last scene. He perceived that the man who had fought thus was magnificent. ... He felt that he was a fine fellow. He saw himself even with those ideals which he had considered as far beyond him. He smiled in deep gratification" (50).

\section{From Self-Satisfaction to Flight}

The idyllic contemplation of a test of valor withstood bravely proves ephemeral, however, as the halt in the fighting proves but a pause. Presently, Henry and his comrades realize the battle has only begun. He tells himself, "this impossible thing [i]s not about to happen," but, sure enough, a "second banging" begins (51). The fatigue of combat has taken its toll, sapping Henry's courage, just as a new wave of blazing guns darts out of the smoke. Two inner forces put him at peril: a loss of nerve that resembles paralysis, making him almost a stranger to his own body, and the psychological trap of overestimating the enemy. The same fear-induced transference that, both in camp and advancing to the front, had made him believe his fellow Union soldiers possessed consummate courage, now occasions his attributing the same to his foes - precisely what he, in heightened touch with his feelings, knows he lacks. In this instance, his neck twitches, his arms grow lifeless and "[h]is hands, too, seemed large and awkward as if he was wearing invisible mittens.... He began to exaggerate the endurance, the skill, and the valor of those who were coming"(51). His doing so diminishes his fortitude and spirit.

Crane is at his figurative best in foreshadowing Henry's flight by describing that of a neighboring soldier whose heroic visage seemed the picture of resolve: 
A lad whose face had borne an expression of exalted courage, the majesty of he who dares give his life, was, at an instant, smitten abject. He blanched like one who has come to the edge of a cliff at midnight and is suddenly made aware. There was a revelation. He, too, threw down his gun and fled. There was no shame in his face. He ran like a rabbit. (51-2)

Seeing others back out of the battle snaps Henry out of his funk. Convinced he is being abandoned, he, too - motivated, perhaps, by the same "consciousness always of the presence [or absence] of his comrades" - runs, albeit not, at first, toward the rear: "For a moment in this great clamor, he was like a proverbial chicken. He lost the direction of safety. Destruction threatened him from all points" (52). Crane here displays what Starrett, comparing Crane's poetics favorably to those of Tolstoy, calls Crane's "instinct for the rowdy commonplace, the natural, the irreverent, which so materially aids his realism" (10). He does so by listing quotidian physical items - Henry's unbuttoned coat, flapping cartridge box and trailing canteen - before providing the screeching detail: "On his face was all the horror of those things which he imagined" (52). After 40 pages inside Henry's head, the reader well knows what "those things" are. Yet, despite Starrett's claim to the contrary, the quotidian is accorded similar treatment in "Sevastopol in August" as the brothers cross the pontoon bridge from the city's North Side to its besieged South Side and center, with water splashing their feet and the sound of bombs growing "louder and louder." His first time in a war zone,

[t]errible fear suddenly overcame Volodya. He felt as if a ball or a bomb-splinter would come the next moment and hit him straight on the head. . . "But perhaps it is too late, it is already decided now, thought he, shuddering, partly at that thought 
and partly because the water had soaked through his boots and was making his feet wet (164).

In Henry's case, running only enhances his sense of peril, since, now, he is exposed where any military formation or soldier can least afford to be - in the rear: "Since he had turned his back upon the fight his fears had been wondrously magnified. Death about to thrust him between the shoulder blades was far more dreadful than death about to smite him between the eyes. When he thought of it later, he conceived the impression that it was better to view the appalling than to be merely within hearing" (52). The sight of men to either side and the sound of footsteps behind him make Henry think he is, at least, in abundant, if not such good, company. Outpacing the others becomes an exercise in self-preservation, since "the initial morsels of the dragons would be those who were following him" (53). As Henry enters "a region of shells," the reader of both works is likely to recall Tolstoy's descriptions of bombardments. They are many, ranging from one viewed dreamily from afar by a little girl who lived next door to Mikhaylov - "Look at the stars! Look how they're rolling! ...What is it a sign of, mother?" (112); to the spectacle Kalugin, reverting to French, comments on to Galtsin over tea and crackles "Quel charmant coup d'oeil, a? [What a charming sight, eh?] (110); to the momentarily indecisive, then suddenly menacing, pinprick of light - seen through a sharp, hyperrealistic lens, headed straight for Mikhaylov and Prashkukhin, and destined to kill the latter: "The bright spot seemed to have stopped at its zenith, in the position which makes it absolutely impossible to define its direction. But that only lasted a moment: the bomb, coming faster and faster, nearer and nearer, so that the sparks of its fuse were already visible and its fatal whistle audible, descended toward the center of the battalion" (126). 
In contrast to this elaborate take on a fast-approaching missile, Crane personifies projectiles in phobic fashion, rounding out descriptions with alluring alliteration: "They hurtled over his head with long wild screams. As he listened he imagined them to have rows of cruel teeth that grinned at him. Once one lit before him and the livid lightening of the explosion effectually barred the way.... He groveled on the ground and then springing up went careening off through some bushes" (52).

After a lengthy time lost, the youth chances upon a general, resuming the theme of his contempt for mounted officers. In this case, Henry "would like to thrash the general," or at least tell him off (54). He considers advising him that "the force was in a fix" until, approaching the officer's steed, he sees him prancing about exclaiming his soldiers' success in reversing the Rebels: "Yes, by heavens, they've held 'im! They've held "im" (54-5). What should be welcome words to any Union soldier come as a death sentence to Henry's morale. While “the general beamed upon the earth like a sun . . . his eyes desir[ing] to chant a paean ... and held a little carnival of joy on horseback," Henry could only "cringe . . . as if discovered in a crime" (56-7). So, at the outset of Chapter VII, begins the youth's long, dragged-out penitential phase. At first, he tries on every argument to justify his flight as "the work of a master's legs" (56). Self-righteousness over his "sagacious" actions in saving his skin gives way to anger at those comrades who had stood their ground, then to the prospect of humiliation before his comrades, and, finally, to self-pity as a victim of "hateful circumstances" (57). Enveloped in guilt, his mien becomes that of a criminal incapable of explaining his offense, and, head hanging, he wanders from an open field into a dense forest "as if resolved to bury himself" (57). 
Such is his paranoia that even normally neutral, or consoling, Mother Nature, at first, offers no solace. On the contrary, twigs and branches condemn him at the same time they betray his presence, and the forest, itself, is constantly "calling out protestations" (57). With nowhere else to go, Henry plows through the underbrush, aghast at how the "disturbed foliages waved their arms and turned their face leaves toward him"; he fears they might call the attention of his fellow soldiers, whose indictment would be severe (57). Shortly, though, Henry feels empathy emanating from his sylvan surroundings, which are as disinclined to behold bloodshed and killing as he.

Youth Schooled by a Squirrel

A farm boy's idle pastime serves to turn his thoughts and fate around by giving his fear-induced, shame-inducing, flight a natural framework. Although critics commonly point to a subsequent incident as the turning point of the novel, this is where Henry, who has grown up among animals, understands that his nature, in one profound respect, is no different from theirs or their mutual Creator's. Sitting amid deep woodland silence, "[h]e threw a pine cone at a jovial squirrel, and he ran with chattering fear. High in the treetop he stopped, and poking his head cautiously from behind a branch, looked down with an air of trepidation" (58). Seeing himself in the squirrel,

[t]he youth felt triumphant at this exhibition. There was the law, he said. Nature had given him a sign. The squirrel, immediately upon recognizing danger, had taken to his legs without ado. He did not stand stolidly baring his furry belly to the missile, and die with an upward glance at the heavens. On the contrary, he had fled as fast as his legs could carry him; and he was but an ordinary squirrel, too doubtless no philosopher of his race. The youth wended, feeling that Nature was 
of his mind. She re-enforced his argument with proofs that lived where the sun shone (58).

This is the first of two consciousness-changing encounters Henry happens upon in these solemn woods. Pushing on from "obscurity into promises of a greater obscurity," he enters a chapel-like bower exuding a semi-religious air and spots a dead soldier seated against a tree (58). The sight of the rapidly decomposing corpse, already an excavation site for teeming ants, makes Henry shriek and stop in his tracks. His "staring into the liquid-looking eyes [and] exchang[ing] a long look" confirms not only Henry's earlier musings about the repose awaiting the dead, but also other, less comforting, aspects of that condition (59). The quick juxtaposition of these two omens - the squirrel, reacting naturally, as had Henry, to a perceived physical threat, and the corpse, reflecting the inglorious option death poses to a young man - gird him for his return to the ranks. Soon enough, "a tremendous clangor ... a crimson roar" shatters the ... woodland silence, summoning him back to the action, as he, himself, notes the irony of his "running thus toward that which he had been at such pains to avoid" (61). Having taken him to her bosom to ensure him that his fear, being natural, is understandable and forgivable, Mother Nature now lays claim to his person, refusing to release Henry to the mayhem: "Sometimes the brambles formed chains and tried to hold him back. Trees, confronting him, stretched out their arms and forbade him to pass. After its previous hostility this new resistance of the forest filled him with a fine bitterness. It seemed Nature could not be quite ready to kill him" (62).

Henry, though, has promises to keep and dispels the woods' seductive spell by seeking "ways to flee ... toward the "long gray walls of vapor where lay battle lines" 
(62). Having looked death in the eye, he passes other corpses, feeling little disquiet aside from that of being an intruder. The general retreat of bloodied, mangled soldiers displays "the awful machinery in which they had been entangled" in what vies with the Crimean conflict as the first "modern war" (64). Reflecting the tattered condition of Henry's soldierly reputation, a "tattered man" approaches the youth and tries to befriend him, but his praise of the "fellers" who gallantly fought and "showed what they was" sticks a finger in Henry's psychic sore; despite the man's amiable nature and "lamblike eyes," Henry keeps his distance (65). Once the man, sporting a bloody wound to the head and another to an arm rendered useless, asks in a kindly manner where Henry had been hit, the latter panics and, invoking distance as a decoy, evades the query by ditching the man, albeit not before feeling his shame fully displayed. In a nod to Nathaniel Hawthorne, the narrator notes that Henry senses his comrades "contemplating the letters of guilt he felt burned into his brow" (67).

Walking amid "a mob" of bloodied men, Henry envies them their wounds, and considers the only replacement for the imaginary, yet palpable, scarlet letter on his forehead to be "a red badge of courage" (67). The next paragraph presents that very badge in all its ghoulish glory in the person of a "spectral soldier ... [and] a stalking reproach" to Henry that will stalk the youth for the rest of his days (67). The man's enfeebled condition evokes the ministrations of his fellow maimed hobbling along beside him, yet his stoic composure keeps them at bay. Henry recognizes the man's gestures as he waves off would-be helpers, and, rushing to look in his face, finds, to his horror, Jim Conklin. 
Back in the forest chapel, Henry had first encountered death up close in a hideous, impersonal, guise; now, he comes to know its true agony as it appropriates his closest friend among the ranks - the humble, homespun, "tall soldier," who had bucked up Henry's courage in what must now seem an earlier life. We know nothing of Henry's father, and Jim Conklin comes as close to a father figure as anyone Henry, in the course of the book, has known. Jim had held his ground against the Rebel charge Henry had fled and is paying the price the latter evaded. Henry now tries to steer his bosom friend off into a field to avoid his being trampled by horsemen or caissons also heading toward the rear. The next thing he knows, Jim tears off across the field toward a bunch of bushes as he instinctively seeks a spot in which to suffer "the rendezvous" he knows is coming (71). Shortly, he falls victim to a ghastly dance of death that Henry can neither halt nor comprehend. Sinking to the ground, Henry repeatedly cries out his friend's name, then watches him slam to the earth with such force that he bounces, evoking a "God!" from the tattered man, who had kept pace in Henry's pursuit of Jim (72). Regaining his feet, Henry approaches his friend, beholding a paste-colored face twisted in anguish and an open mouth sporting a frozen laugh. As gravity peels away "a flap of the blue jacket" Jim is wearing, Henry gets a clear view of the side of his friend's body and notes that Jim, for his valor, had earned a mortal wound that "looked as if it had been chewed by wolves" (72). Red badge of courage, indeed.

His tongue "dead in the tomb of his mouth," Henry proves unable to "screech his grief" and reclaim his feet until he notes the tattered man displaying symptoms of infirmity that make Henry sense the stranger, too, might be a goner (73). Only then does Henry rejoin his good-natured sidekick, who repeatedly calls their late comrade "a reg'lar 
jim-dandy" due to the convulsive drama of his death (73). The man's description of his own wounds opens the door to queries about the location of Henry's, thereby “upraising the ghost of shame on the stick of [his] curiosity"; the poor man's persistence, driven by innocuous concern, strikes Henry as an Inquisition or, at least, a lever designed to unseal a can of worms, inciting him, again, to flee the man (75). Now, though, Henry yearns not for a red badge courage, as he had the first time he fled him, but for the grave, itself: "He now thought he wished he was dead. He believed that he envied those men whose bodies lay strewn over the grass of the fields and on the fallen leaves of the forest" (76).

This desire derives from a motive different from that he, untested and unsure, had felt back in camp. Whereas, previously, he had been unable to live down his fear of being maimed or killed, now he proves unable to live down his fear of being discovered. On numerous occasions in the Sevastopol Sketches, soldiers fear having their fear detected, but only once does a character, arguably, shirk his duty, as does Henry - namely, when Kalugin passes on false information obtained from Mikhaylov regarding progress on the lodgments, whither a general had ordered Kalugin go in person, albeit not under the kind of heavy fire reigning at the time (122). Kalugin ducks into a bomb-proof shelter, where an officer calls him on the carpet for reporting that "'the affair is over.' 'Over? How so?' inquires the officer. 'On the contrary, the general has just gone again to the watch tower and another regiment has arrived"' (122). Kalugin moves as if to get up and go carry out his duty when the sound of musketry outside the shelter prompts the officer to insist he stay put. 
Fear Moves from Primal to Purgatorial Plane

This, though, is just a hint of what Henry feels - a sense of mild embarrassment compared to outright shame. Fear transformed lends legs to The Red Badge by rendering it a uniquely layered plotline, one in which the same emotion - fear - moves from a primal to, perhaps, a purgatorial plane, on which Henry feels damned as a deserter, yet seeks redemption - and now, prompted by vengeance for the enemy's killing of his friend, finds the moral wherewithal to attain it. Since his need to redeem himself requires a return to his regiment, deception becomes Henry's modus operandi until he returns to battle and manages to lose himself in its pure, intuitive fury. His stealth and stratagems present a curious counterpoint to the relentless soul-searching in which Henry engages as he vies to reenter the fold: Returning whither he must go to restore his integrity requires deceiving others. This process begins in earnest after Henry flees the tattered man a second time. He takes comfort upon beholding "a crying mass of wagons, teams and men" not only pursuing the same rearward course he had taken, but doing so under the same motivation: "Fear was sweeping it all along" (78). The mathematical leitmotif Henry had called on earlier, first, to show he wouldn't run and second, to confirm it, reappears. "The thing with which men could charge him was in truth a symmetrical act" he reasons, taking "pleasure ... in watching the wild march of this vindication" (78).

When an infantry column bound for the front bores its way through the retreating swarms, the "men at the head butt[ing] mules with their musket stocks," Henry again transfers onto them all the fearless resolve he has found missing in himself (78). He concludes that "he could never be like them," then scours his mind for "an adequate malediction for the indefinite cause" - something he can point at, identify and condemn 
(79). The chances are fear is the culprit, but Henry can merely identify the pronoun: It whatever it was - was responsible for him. There lay the fault (79).

Mathematical formulae having failed him, Henry now appeals to existential sleight-of-hand to assuage his self-contempt and address the envy he feels for those men heading into battle. He longs to "change lives with one of them ... to use a tremendous force .... throw off himself and become a better" (79). Immediately, the aesthetic condition reemerges, as "[s]wift pictures of himself, apart, yet in himself, came to him - a blue desperate figure leading lurid charges with one knee forward and a broken blade high - a blue, determined figure standing before a crimson and steel assault, getting calmly killed on a high place before the eyes of all. He thought of the magnificent pathos of his dead body" (79-80). These musings resemble a condensed version of the page-long reverie in which Volodya engages while riding along the Belbek River with his elder brother, Michael, in the back of the trap bound for Sevastopol (Chapter II, Part 3, Page 4 above). Henry, too, derives inspiration from his thoughts and, for the first time in what seems an eternity, feels "the quiver of war desire" and hears "the ring of victory" (80). Other quotidian sounds of battle "made him soar on the red wings of war. For a few moments he was sublime" (80).

Emboldened as the caissons keep rolling rearward, Henry is suddenly eager to start for the front, where he will "seize and throttle the dark, leering witch of calamity" (80); yet, practical matters stand in the way: He has no rifle, albeit plenty are at hand; he could disguise himself in "the battle blur" but only until another "tattered man" appears questioning his earlier whereabouts; he would never locate his regiment, although these, too, were abundant, and he could fit in with any. This series of thoughts represent a new 
conflict, in which "[d]oubts and he were struggling" - this time not over his ability to face fire but over whether he'd be shown to be a coward, whether it mattered that he'd fled, whether he'd be able to rectify his flight, and whether a rout might not give the cover required for him seamlessly to rejoin the ranks of his "sullen brothers in distress" (80). A wealth of irreconcilable considerations pushes and pulls the youth, yet "a certain mothlike quality within him" - his sense of duty - keeps him skirting the battlefield (81). Unable to flee the fringe of the fray and return home a coward, he tries to muster the moral and mental wherewithal to head back into not only the battle, but also - first - the inquisitional gauntlet he will have to run before being able even to shoulder a rifle. Crane reverts to military imagery reminiscent of that used in "George's Mother" upon noting of Henry: "He stepped as if he expected to tread upon some explosive thing" (80).

\section{Henry Touches Bottom}

Negotiating such a terrain is made worse with Henry's mind swirling in a vortex of self-loathing, which converts what would be a mere conundrum into a Cavalry, as the youth lashes out at himself in terms ranging from "despicable" to "villain" to "the most unutterably selfish man in existence" and, due to his betrayal of the cause, even a "murderer" (83). His self-flagellation proves so intense that he imagines the scars visible to all. The son of a "Republican mother" willing to sacrifice her only child to the "success [of the] mighty blue machine," he has before him but one choice: vindication (83). The need to find a way - any way - to feel himself, again, "not a man but a member" no different from his fellows, by proving he can stand up to fear, becomes a moral imperative and prods Henry, by hook or by crook, to reengage himself in the conflict and cause. Pondering those who have given "the last full measure of devotion," 
Henry dismisses them as unlucky saps, killed before they had a chance to run away, as he, in his perspicacity and wisdom, had; nevertheless, he envies them whatever clean conscience escorted them to the grave (Lincoln).

Here, Henry reaches the nadir of his shame. Given the make-up of the Union's volunteer Civil War groupings, this contempt was bound to hound Henry into post-war civilian life. In The Vacant Chair: The Northern Soldier Leaves Home, Reid Mitchell notes that "the company, the basic military unit, functioned as an extension of the soldier's home community." (21) From talking to the Orange Blossoms, Crane was certain to have learned that "[i]n most ways, a soldier's company was the army for that soldier. .. . Companies and regiments were raised by local leaders in specific towns and counties; the soldier's officers and fellow soldiers were most often men he had known all his life" (Mitchell 22).

When Henry, sunk in self-doubt, assessed the mettle of his mates during their march to the front and first battle, the narrator made clear that he "had known many of his comrades since boyhood" (21) - hence, the "cruel stares," "wide derisive grins" and shouts of "There he goes!" that Henry now imagines are likely to plague him for the rest of his days should he not get back to the front and make his presence known to not only his comrades, but the enemy, as well (84). Here, we find another flip side to the vainglory that had seduced Henry before he entered battle under the delusional aesthetic condition of fantasizing heroic deeds. It may prove the catalyst that marks the definitive turning point of the story.

As Henry beholds a full-scale retreat, the narrator returns, again, to the schoolhouse to describe the youth's embrace of the sight. This time, he needs no 
rationalization to fathom the fact that fear is universal and may, even, serve a purpose: "He threw aside his mental pamphlets on the philosophy of the retreated and rules for guidance of the damned" (85). As had he, himself, seemingly eons ago, the panic-stricken men run "hither and thither in all ways" thanks to the ubiquitous artillery making "a jumble of ideas of direction" (86). The participants in this mass exodus being hundreds of "very burly men," again, humanizes Henry, who, in comparison, is but a lanky waif hence, perhaps, more prone to fear. Of equal importance to the novel's theme and plot, it sparks the tinder of his dormant yet innately patriotic spirit, causing him to oppose the rearward charge. If he, that morning, had been a "murderer" for turning tail, what he now recondite - is witnessing is a mass of murderers. He first seeks to "make a rallying speech, to sing a battle hymn, but he could only get his tongue to call into the air: 'Why why - what - what's th' matter?"” - the very question he has been asking himself ever since fear seized him by the throat earlier that day (85). The juxtaposition to Chapter XI is total, as what had been a "procession of chosen beings" (as distant from him as virtue from vice) marching to the front becomes a frenzied mass retreat that Henry valiantly, if foolishly, tries to halt (79). In so doing, he resembles the boy in the Hans Christian Anderson tale sticking his finger into the crumbling dike.

This image and association might have been the very ones Crane wished to evoke, given the historical background to this phase of the battle of Chancellorsville, which, he chose as "his model ... as even the most elementary student of the conflict can plainly see from point to point in Crane's account" (Foote xxx). Any reader will notice that, of all the peculiar language found in a book steeped in vernacular, two passages, syntactically speaking, stand out as the oddest: Where de plank road? Where de plank road?" and "Let 
go me! Let go me!" Shelby Foote identifies this rearward swarm of soldiers as "O. O.

Howard's rattled Dutchmen, numbers of whom--skedaddlers too, but faster on their feet, [were] thrown rearward in panic by [Confederate General Stonewall] Jackson's flank attack (xxxiv). $* \square$

Upon reverting to physical measures to stem this tide, Henry earns the "red badge of courage" he had coveted ever since the tattered man had left his pride in tatters at the close of Chapter VIII by innocuously asking "Where yeh hit?"; at that time, Henry merely blurted, "Why ... I - I - that is - why - I-" (66). Now, witnessing the mass retreat, Henry twice utters the same three-letter word, this time as "interrogations," while clutching an urgently fleeing soldier by the arm: “"Why - why -' stuttered the youth" (86). The grammatical reversal reinforces the change in the character's disposition as subtly as had the preceding mathematical motif. Henry's insistence on holding the man, however, results in a violent reaction, as the latter, fighting to free himself and continue

* Regarding the historical background to Foote's observation: "In the spring of 1863, following his promotion to major general, Howard was elected to replace Franz Sigel as the head of the XI Corps. A revolutionary from Germany, the immensely popular Sigel was the perfect choice to lead the predominantly German unit. Howard, however, with his penchant for strict military and moral discipline, did little to gain the respect of his troops before the battle of Chancellorsville. Posted on the right flank on May 2, 1863, Howard's men bore the brunt of Stonewall Jackson's devastating flank attack. Though the corp commander displayed personal bravery in attempting to rally his troops, many — including Army commander Joseph Hooker — blamed Howard and his "flying Dutchmen" for the Union rout. These same troops would flee in confusion two months later at the battle of Gettysburg. Howard later headed the Freedman's Bureau and became the namesake of the nation's first university for Afro-Americans (CivilWarTrust).

$\neg$ For the sake of verisimilitude, Crane might have better conferred with a German grammar book or teacher, since the syntax of the latter statement, in which the soldier orders Henry to release him, would be the same as in English, i.e. "Lass mich frei"or "Lass mich gehen" (Let me go.) (Author's note.) 
retreating, "adroitly and fiercely swung his rifle [which] crushed on the youth's head" (86).

The blow - dealt him not by a Confederate but by an allied Dutchman incapacitates Henry as much as had the fear he had felt before fleeing the second wave of the Rebel attack. His red badge serendipitously acquired, Henry is as if reborn - at least in a physical sense, if not yet a psychological one: Having collapsed to the ground, he struggles "like a babe trying to walk, to his feet" (86). Courageously, he vies to keep afoot. In what would be a cruelly ironic twist had it not some redemptive value, Henry emulates his fallen friend, going "tall soldier fashion" to find a place to lay himself down (87). This reference to Jim Conklin, the truth-speaking prophet doubted by many on the eve of battle, awakens the image of "the red sun pasted in the sky like the wafer" that hung above the "ceremony at the place of meeting," where we last saw Jim (72). That wafer, in Christian communion, represents terrestrial resurrection. Henry, who had, on that occasion, uttered "Hell-" - a term expressive of the moral morass in which he was groveling - has now returned to life, and, before the page is out, the Christian theme is reinforced, as a cheery-voiced comrade miraculously comes to his aid. This Good Samaritan overcomes every obstacle in leading Henry, if not straight to an inn, as in the Biblical parable, then straight to his regiment. The selfless charity of this gesture Crane portrays through a technique reminiscent of that he had employed to exhibit the ordinariness of the soldiers: "As he who had so befriended him was passing out of his life, it suddenly occurred to the youth that he had not once seen his face" (91). Nameless. Faceless. Everyman. Christ. 
Further fortune greets Henry as he approaches the campfire full of misgivings and guilt. Physical exhaustion, alone, keeps him from evading this unexpected reckoning with his peers, to whose "barbed missiles of ridicule ... he would be a soft target" (92). As luck would have it, who confronts him at the sentry post and welcomes him back into the fold but Wilson, the formerly cocky, loud-mouthed soldier, who, prior to battle, had entrusted Henry with the good-bye letters to his family in the event he shouldn't survive. Having "give[n him] up fer a goner," he is delighted to see Henry again (92). The newcomer repeatedly lies about his wound and recent whereabouts, saying, "I got shot. In th' head. I never see sech fightin'. Awful time. I don't see how I could a got separated from th' reg'ment. I got shot, too" (93).

A corporal "at that moment loomed in the gloom," posing a threat to Henry's blending back into the ranks; yet, the officer quickly recognizes his charge, expresses surprise, and readily makes it known that Henry - crutching himself on circumlocution was not alone in disappearing from battle (93). As if a blessing, the Christian motif continues in the corporal's exhortation: “Great Jerusalem, they keep turnin' up every ten minutes or so! We thought we'd lost forty-two men by straight count, but if they keep on a-comin' this way, we'll git th' comp'ny all back by mornin' yit” (93). If misery ever loved company, it is when this soothing news hits Henry's ear. It fails to throw off his wariness, though, and he responds adroitly when the corporal asks the simple, yet potentially loaded, question "Where was yeh?” to which Henry "glibly" answers "Over on the right. I got separated" (93).

The homecoming grows warmer as the now good-natured, if gullible, Wilson, readily reminds the officer of the first order of business: tending to the newcomer's 
wound. He does so "like a blacksmith," but, with loving care, gives Henry his blankets, and lays him down to ease his aches and sleep off his exhaustion (96). The narrator treats the wayward youth even more gently, allowing Henry to reincorporate himself discretely into the ranks by timing his arrival amid most of the regiment's wooden slumber. "He gave a long sigh, snuggled down into his blanket and in a moment was like his comrades" (97). The prodigal son has returned to the fold, and Crane's Christian upbringing, again, channels the plot.

The narrator, here, reverts anew to the parallel development first encountered with Jim Conklin and, as mentioned at the outset of this chapter, transferred to Wilson; now, though, both soldiers have been in battle, so neither is looking to the other for advice or consolation. The two will grow as close to brothers-in-arms as humanly possible, first vying to take over the regimental battle flag after its bearer is shot and killed - a contest Henry wins - then leading two charges that result in the friend's capturing the enemy battle flag. Now, though, the narrator deepens the Christian theme of forgiveness and signals Henry's burgeoning transition by showing that of Wilson, identified two days before as "the loud soldier" (19). The former "blatant child with an audacity grown from his inexperience, thoughtless, headstrong, jealous and filled with a tinsel courage" has grown humble, humane and genuinely courageous; he not only administers to his wounded comrade as to his own brother or son but also breaks up a fight between three neighboring soldiers - one of them a tough (100). Foremost, Wilson acknowledges his former failings, as the narrator registers his growth:

"I believe I was a pretty big fool in those days." He spoke as after a lapse of years (101). 
Now referred to repeatedly as "the friend," Wilson unwittingly performs the friendliest of offices upon expanding on the corporal's words: Many are the missing. ““Th' reg'ment lost over half th' men yesterday,' remarked the friend eventually. 'I thought 'a course they was all dead, but laws, they kep' a-comin' back last night until it seems, after all, we didn't lose but a few. They'd be scattered all over, wanderin' around in th' woods, fightin' with other reg'ments an' everything. Jus' like you done'” (103).

After Henry's seemingly interminable psychological solitary confinement during which a squirrel, alone, was able to offer succor and the kindness of strangers had to be curbed unless an off-the-cuff query stir up his guilt and send him packing Wilson's final sentence incorporates Henry back into humanity. He hadn't been alone in taking off to save his skin. He may have erred in throwing down his rifle, but evidence indicates others had done the same. It might also show he had not been mistaken, were it not for Jim Conklin and others who had stood their ground and paid the final price. Henry, at any rate, is alive to fight another day - most likely, on the morrow.

As does any paranoid soul, Henry remains suspicious of any and all, so Wilson, despite his probing - as ingenuous as was that of the tattered man and the Good Samaritan - proves the perfect party to receive him - again, not because Henry instinctively trusts him, but because Henry has the means to quash any hint of revelation Wilson may expose. Henry "had been possessed of much fear of his friend, for he saw how his questionings could make holes in his feelings," yet Wilson's earlier moment of weakness, which had preceded Henry's, gives the latter the upper hand, making him "master. It would now be he who could laugh and shoot the shafts of derision" (105). 
In, perhaps, the novel's most peculiar and dramatic turn, the formerly hapless, self-disgusted, groveling, blackguard deserter - Henry Fleming - whose history has in no way changed, although his circumstances have improved, finds himself with the upper hand vis-à-vis the friend who is restoring him to life; oddly, Henry feels himself “immensely superior ....inclined to condescension [and possessing] an air of patronizing good humor" toward his comrade, who, in confidence and with heartfelt sincerity, had shared a moment of existential doubt with the youth before a battle Wilson would weather and Henry, flee. (105). Cunningly, Henry finds the means to shed his past and become, suddenly, irreproachable, while in a position, should need arise, to reproach his friend - although the latter had outdone him as a soldier in standing his ground against the Rebel onslaught. A more forthright and truer comrade might have confessed his fear to a fellow who had once shared his foreboding and now, singlehandedly, reintroduced him into the ranks, making Henry, at least for appearances' sake, morally whole again. Instead, the youth - perversely, perhaps - opts to keep secret his moment of weakness an experience now shown to be shared by countless soldiers he, himself, has seen. Nonetheless, the transformation owes entirely to Henry's capacity to keep his act of cowardice under wraps - an unlikely catalyst to inner growth and subsequent heroism, unless it work as the grain of sand in an oyster shell that gives birth to a pearl:

His self-pride was now entirely restored. In the shade of its flourishing growth, he stood with braced and self-confident legs, and since nothing could now be discovered he did not shrink from an encounter with the eyes of judges, and allowed no thoughts of his own to keep him from an attitude of manfulness. He had performed his mistakes in the dark, so he was still a man. (105) 
We encounter this instinct repeatedly in "Sevastopol in May," as in the incident in which Kalugin, who prides himself on his valor, hits the deck upon seeing a missile heading toward him. After the bomb explodes a good distance off, he upbraids himself while regaining his feet and "looking around to see if anyone had noticed his downfall, but no one was near" (117). In Henry's case, this tendency may well grow from the makeshift way in which regiments were formed in the Civil War, and the poor training provided Union soldiers in a country that had not witnessed a major conflict in more than a generation (the Mexican War of 1836 having been notoriously one-sided). PostCrimean War Russian military training might shed light on the missing ingredient that, effectively, underpins the plot of The Red Badge:

Self-denial in [Michael Ivanovitch] Dragomirov's scheme constituted the antipode to self-preservation. The key to the victory of self-denial over selfpreservation was drill, especially the training of obedience. The most effective antidote to fear, in other words, was practice and routine. It was only logical that maneuvers in peacetime ought to be as realistic - as fear-inducing - as possible (Plamper 270).

Pride Comes After the Fall

Rapidly mustered and drilled in a hurry, Union forces, at the war's onset, might have lacked in the training needed to become stolid soldiers; hence, their training came in the course of initial battles, themselves. Stranger yet is the effect this sudden, new-found certainty works on Henry, granting him "license to be pompous and veteranlike" (105). We might as well be back among the white-gloved crowd on the boulevard in Sevastopol. Henry appears, finally, to have mastered his math and graduated from the school bank, 
since he no longer needs to "give a great deal of thought to great battles ...[or] plan his ways in regard to them" (105). Combat by equation has succumbed to a swashbuckling, no-holds-barred attitude that characterizes the new Henry:

He could leave much to chance. Besides, a faith in himself had secretly blossomed. There was a little flower of confidence growing within him.... He had been out among the dragons... and he assured himself that they were not so hideous as he imagined them. Also, they were inaccurate; they did not sting with precision. A stout heart often defied, and defying, escaped (106).

This is all well and good. After everything Henry has suffered, and given his penchant for moral integrity despite a checkered past - or past 24 hours - the dramatic change proves both welcome and refreshing. The next sentence, though, shows Henry's psyche so inflated that even the boulevard would fail to contain it: $[\mathrm{H}]$ ow could they kill him who was the chosen of the gods and doomed to greatness?" (106) Despite their having run away with the same "terror-struck faces" he must have worn, Henry holds his fellow deserters in contempt as "weak mortals" compared to him, who "fled with discretion and dignity" (106). What should rouse him out of his latest flight - this one of fancy, on the wings of the aesthetic condition - but the discrete coughing of his "friend," which has the same shattering effect on Henry's musings as the boulevard music had had on Michaylov's in "Sevastopol in May." Wilson, whom Henry will allow only so near, has come to inquire about the very anchor holding Henry in place: the letters he, in what now seems another lifetime, had entrusted to the youth the morning before. As he had when first sizing up his standing with his "friend," Henry decently refrains from lording it over Wilson or saying something that would shame him. The latter's flushed face, 
turned from Henry as he makes his request, reflects shame enough. To his discredit, however, Henry, rather than show fellow feeling, resorts to comparing himself to his counterpart (favorably, of course, despite the latter's having stood firm and fought while Henry fled), noting that "he [Henry] had never been compelled to blush in such manner for his acts; he was an individual of extraordinary virtue" (107). Appreciating Henry's compassion, readers may partially concede as much, albeit, aware of his former hightailing ways, they may find an eyebrow moving irrepressibly skyward. The Sevastopol boulevardiers' exaggerated self-assessments go hand-in-glove with Henry's, which, before the pivotal Chapter XV's close, expands into future, self-aggrandizing fictions, again reminiscent of Mikhaelov pondering his "Pupa":

After this incident, and as he reviewed the battle pictures he had seen, he felt quite competent to return home and make the hearts of the people glow with stories of war. He could see himself in a room of warm tints telling tales to listeners. He could exhibit laurels. They were insignificant; still, in a district where laurels were infrequent, they might shine.... He saw his gaping audience picturing him as the central figure of blazing scenes (107).

Henry has, of yet, done little to merit such acclaim, but, given his valiant performance to come, one may acknowledge the uncanny wisdom of e.e. cummings' marvelous quip, “[d]eeds can’t dream what dreams can do" (511). Nonetheless, Henry grows boastful and, suddenly, erudite on the subject of military strategy - this, despite his most decisive mobilization, so far, having been toward the rear. When reports of feckless leadership greet his ears, he readily strikes a superior pose: “'B'jiminey, we're generalized by a lot 'a lunkheads.' 'More than one feller has said that t'day,' observed a 
man. 'Well, don't we fight like the devil? Don't we do all that men can?' demanded the youth loudly" (110).

Such delicious irony is hard to resist, and even the speaker, himself, is stunned by his words: "He was secretly dumbfounded at this sentiment when it came from his lips. For a moment his face lost its valor and he looked guiltily about him. But no one questioned his right to use such words, and presently he recovered his air of courage" (110). In the worst kind of hypocrisy, Henry next starts talking up the regiment's bravery the previous day, prompting a "sarcastic man" nearby to burst his braggadocio by quipping, "Mebbe yeh think yeh fit th' hull battle yestiday, Fleming" (110).The comment cuts Henry to the quick, "reduc[ing him] to an abject pulp [and setting] his legs quak[ing] privately" (110). Adroitly, Henry quickly assumes a conciliatory tone, acknowledging that his had not been a single-handed effort. A scene more amusing than this is hard to find outside of Ring Lardner or Hunter Thompson.

To Henry's good fortune, the man refuses to push the matter: "Apparently, he had no information" (111); the unexpected challenge, nonetheless, teaches Henry to hold his tongue, and he "became suddenly a modest person" - exactly what his mother had told him to be (111). Henry keeps his grumbling to within his friend's earshot until a lieutenant tells the two to put an end to their "chin music"; the admonishment comes just in time, as a "rolling thunder" of combat besets the woods, engulfing the weary regiment as it had the day before (112). Nonetheless, fleeing no longer seemed a moral option: "They stood as men tied to stakes" despite their foe's renewed, relentless fury (113). This scene is emblematic of a recurring, fear-inducing theme that marks Crane's work one which Sorrentino explores in his chapter on Crane's coverage of the Greco-Turkish 
War; already famous as an "author of war fiction," Crane purportedly sought in Greece to test for himself the veracity of his venerated Civil War novel (240). Together with the author in a trench during a Turkish bombardment of Valestino, New York Journal correspondent John Bass asked Crane about his impressions of the battle. Crane replied, "The Greeks [among whom he was reporting] I can see and understand, but the Turks seem unreal. They are shadows on the plain - vague figures in black, indications of a mysterious force" (242). [The remark, in Sorrentino's view, is indicative of Crane's] “own ongoing personal battle ... between an individual's limited understanding of reality and an inscrutable force in nature" (242). The cylinder of vision through which an unseasoned soldier views a horde of ill-wishing enemies readily makes an adversary seem indomitable, and this perception is likely to awaken an equally indomitable fear in a perceptive youth, despite the visions of glorious heroics that had lured him to the engagement. The only hope such a soldier has lies in his faith in, and reliance on, his peers. This is the lesson Henry's mother had taught him upon leaving home, when she admonished him, "Don't go a thinkin' you can lick the hull rebel army at the start because yeh can't. Yer jest one little feller amongst a hull lot of others" (13). It is also the lesson he learned from his first battle: "He became not a man but a member" ... [and] could not flee no more (sic) than a little finger can commit a revolution from a hand" (44). This same enemy resilience occasions a psychological change in the youth based on his ability to direct his anger outward at a specific menace - not outward at an abstraction, as he had before his first battle, nor inward, at himself, as he had after fleeing the second enemy onslaught: "Yesterday, when he had imagined the universe to be against him, he had hated it, little gods and big gods; today he hated the army of the foe 
with the same great hatred. He was not going to be badgered of his life, like a kitten chased by boys, he said. It was not well to drive men into final corners; at those moments they could all develop teeth and claws" (114).

The sense of being an impotent, victimized innocent returns within a few paragraphs, prompting “a dark and stormy specter” of rage within Henry's heart (115). The disdain he now feels for his adversaries makes Henry view them in terms that scale the entire animal kingdom, descending, step by step, from a bullying to a parasitical lot, as he now deems his "tormentors ... flies sucking insolently at his blood" (115). Shortly, both armies descend another link in the evolutionary chain, as "animals tossed for a death struggle into a dark pit," with the foes taking on reptilian aspects: "he and his fellows were pushing back, always pushing fierce onslaughts of creatures who were slippery" (115).

Next, a sense of his weapon's powerlessness makes Henry forget “everything but his hate, his desire to smash into pulp the glittering smile of victory which he could feel upon the faces of his enemies" (116). Accompanying this focused hatred of now, not some abstract war god, but a leeching, venomous foe, comes an intense will to oppose it. Hence, we see Henry assuming "a position behind a tree with a direct determination to hold it against the world" - and, this, despite the odds against triumph (116). In fact, the conviction that defeat is his and his mates' fate this time proves a reason not to flee but to fight harder. Crane, here, expresses the spirit of hard-nosed resistance as well as Tolstoy ever did in describing the defense of Sevastopol. 


\section{From Inner Fear to Outward Focus}

In addition, Henry's focus is such, that, despite the shifts in attacks, alignments, and retreats, he "knew where lay the enemy" (116). This represents a marked evolution of, perhaps, the most important weapon a soldier can wield: instinct. The psychological change affects him physiologically, as well, making him oblivious to pain: "His rifle barrel grew so hot that ordinarily he could not have borne it upon his palms";

nonetheless, he mechanically keeps up the multiple tasks involved in prepping the gun until "he pulled the trigger with a fierce grunt, as if he were dealing a blow of the fist with all his strength" (116). Parallel to his psyche, his manual dexterity has evolved dramatically from that he displayed in the second battle of the previous day, when " $[\mathrm{h}]$ is hands ... seemed large and awkward as if he was wearing invisible mittens" (51). He is now fully engaged, both psychically and physically. In fact, his daring has increased such that he now baits the retreating enemy "like a dog who, seeing his foes lagging, turns and insists upon being pursued" (116). Again, we see Volodya showboating on the Malikov Redoubt: "Joy at fulfilling his duty, at finding that not only was he no coward but that he was even quite brave...made him quite valiant...[W]ith flushed faced and shining eyes [he] clapped his hands, gave the order, 'One - two!' in ringing tones, and ran gaily onto the breastwork to see where his bombs were falling" (1995).

Encountering stiff resistance, Henry, rather than hustle homeward, now "retire[s] slowly, sullenly, taking steps of wrathful despair" (116). His hatred of the foe so overtakes him that he can't even hear when his fellows have ceased firing and has to be brought back down to earth. The fog of war has enveloped him, filling his eyes with "a glazed vacancy. . . He seemed drunk with fighting" (115). The scene returns us to 
"Sevastopol in May," as Baron Pesth - conversely, acting in a funk of fear - bayonets a Frenchman: "[D]uring the whole affair he had been as it were in a fog and so bewildered that all he remembered of what had happened seemed to have happened somewhere, at some time and to somebody...Pesth was is such a fright that he could not in the least make out how long it lasted, where he went or who was who. He went on as if he were drunk" (123-4).

Unlike Pesth - and, oddly, unlike himself earlier on, when beset with vainglorious visions - no Swaggering Soldier emerges after this action, since Henry, now, has no need to embellish his deeds. His lieutenant does it for him: "By heavens, if I had ten thousand wild cats like you I could tear th' stomach outa this war in less 'n a week!' His comrades meanwhile "now looked upon him as a war devil" (116-7). Henry's head now fills with well-deserved self-congratulatory praise; he had fought like "a barbarian, a beast ... a pagan who defends his religion ... a tremendous figure [whose actions had been] fine, wild, and, in some ways, easy" (118). That last adjective marks a new narrative tack contrasting fully with the gauntlet of punishing, labyrinthine mental exertions Henry has traversed since he lay down on his bunk to muse the prospect of battle the first time we met him. His selfless engagement in combat has brought rectification within reach by transforming fear into valor: "By this struggle he had overcome obstacles which he had admitted to be mountains. They had fallen like paper peaks, and he was now what he called a hero. And he had not been aware of the process" (118). His comrades have undergone similar seasoning and now, in the worst soldierly macho fashion, boast of resembling “a dog, a woman, an' a walnut tree" in having taken their licks and rebounded: "Th' more yeh beat 'em, the better they be!” (118) 
"Mule Drivers" Sobriquet Fuels Fighters

Despite the newfound fight Henry and Wilson carry within themselves, they soon overhear their regiment ridiculed by a member of the gloved officer set, the likes of which we once observed strolling the boulevard of Sevastopol. Returning from a fruitless search for a stream in which to fill a dozen or so regimental canteens and assuage the thirst raised by the ferocious battle they have endured, the two hear a mounted officer, in the course of offering their regiment's services for a crucial impending battle, tell the division commander, "They fight like a lot 'a mule drivers"; when the general soberly replies, "I don't believe many of your mule drivers will get back," the officer shouts something inaudible but surely clever, since it brings a smile to his lips, just as it strikes fear into the hearts of the two who overhear the exchange (121). Despite the brevity of the repartee, and the paucity of words spoken, "the youth felt that in them he had been made aged" (122). Whatever healthy humility Henry has acquired in the process of becoming "not a man but a member" of his regiment has now been debased by the officer's callous insouciance toward the fate of the $304^{\text {th }}$.

What makes Crane the quintessential - and, arguably, first - American modernist is the modern psychological thinking made manifest in this novel. The consequential turning point, marked by the transformation of a somewhat passive, self-doubting, everbeset, and utterly Angst-ridden recruit into a soldier ruled by self-determination occurs in Chapter XIX, as Henry joins the charge. The once aimless greenhorn, whose case of the yips had sent him running in another direction, now hustles "toward the prominent clump of trees where he concluded the enemy were to be met ... as toward a goal... [H]e ran desperately, as if pursued for a murder" (124). Crane notes seven characteristics - 
including Henry's clothes, countenance and carmine contusion - that combine to make him "[look] to be an insane soldier" (124). By describing his furious pace as that of one sought for a mortal sin, Crane throws an ironic wrench into the narrative works, since this instance marks the third such reference and comes under circumstances antithetical to those couching the earlier conscience-laden references to souls steeped in moral abjectness from having fled the fight (in the first instance, Henry, in the second, the "flying Dutchmen"); now, the term describes the extreme physical exertions of an integral soul eagerly heading onto the killing field. His constancy amid the sight of menacing, gruesome images - such as "the song of ... bullets ... in the air"; "shells snarled among the treetops"; a bomb that "explode[s] in crimson fury"; and comrades "punched by bullets [falling] in grotesque agonies, leaving] a coherent trail of bodies" further marks Henry's about-face from a young man turning tail to a man intent on threading a hail of lead to conquer a foe (125).

Having shed the psychological shroud of self-absorption, Henry now proves "omnivoyant," were there such a word: "It seemed ... that he saw everything. Each blade of the green grass was bold and clear (125) He intuits subtle variations in the air; the texture of the bark on nearby trees; and his comrades' movements, facial expressions, and gestures, both vital and mortal. Only one thing is missing: the crucial element marking the difference between what Gierick calls "the state of war" and "the action of war": a sense of "why he himself was there" (125). To feel so in touch with life in the face of death, yet not know one's purpose, poses a sense of existential dread to anyone able to ponder the situation, which luxury is denied the active soldier; Henry, of all people, could only rue such ruminations, since they had always served to entrench him deeper than ever 
he was at the front. Nonetheless, this ultimate statement of the foot-soldier's fate must, at least partially, have been what inspired Ford Maddox Ford to note of war writing after Stephen Crane: "The idea of falling like heroes on ceremonial battlefields was gone forever" (preface). The comment resembles a restatement of what Gierigk said of Tolstoy (see epigram to "Sevastopol in December 1854," above). In "The Charge of the Light Brigade," a time-honored poem about the war Tolstoy survived, a compatriot of Ford's famously obviates the very thought that Henry entertains: "Theirs not to make reply/ Theirs not to reason why ...” (Tennyson). Reducing men to beings trained to neither ponder nor question their actions but merely carry out orders and measures aimed at destroying a foe - what Dragomirov called "controlled berserkdom" - may seem horrifying in human terms but proves the most effective way of getting a necessarily deadly job done. If that job is preserving the Union, abolishing slavery, or halting the spread of a murderous Nazi regime - situations involving human rights and the fate of humanity - adopting such a mindless mindset may be not only justified, but essential. Despite her misgivings about his enlisting, Henry's Republican mother, again, showed understanding of what her son, in this regard, might face upon advising him, "If so be a time comes when yeh have to be kilt or do a mean thing, why, Henry, don't think of anything 'cept what's right, because there's many a woman has to bear up 'ginst sech things these times, and the Lord'll take keer of us all" (14). Another Ford compatriot, Thomas Hardy, enlarged on Henry's dilemma upon extending it to embrace the fate of his foe: How quaint and curious war is! / You shoot a fellow down / You'd treat, if met where any bar is, / Or help to half a crown (lines 17-20). Henry had shared such sentiments while standing picket one night across a brook from a "slightly ragged 
[Southern soldier] who spat skillfully between his shoes" and called the youth "a right dum good feller," which accolade "had made [Henry] temporarily regret war" (16). These scenes, in turn, post-date the amiable exchange of cigarettes, trinkets, and French expressions, some better spoken than others, that mark the truce called to remove corpses filling the valley between the Fourth Bastion and the French batteries in "Sevastopol in May 1855." Due, perhaps, to his ability to cope with, rid himself of, or even conquer such uncertainty, Henry in this scene undergoes the metamorphosis he had envisioned and yearned for close to the start of the story: "The youth had been taught that a man became another thing in a battle. He saw his salvation in such a change" (35).

Subsequent descriptions of Henry and his comrades remind one, with certain caveats, of Dragomirov's praise of Russian soldiers "characterized by "a feeling of duty to tsar and fatherland, a feeling that goes as far as self-denial" (Plamper 270). For all its patriotism, such sentiment is not that of free men fighting to extend freedom to others, but defenders of what is, at best, a nationalistic cause growing out of autocratic rule lacking any universal vision. Whatever the underlying motivation, the key point is "the victory of self-denial over self-preservation"; in, perhaps, a chauvinistic fashion, Dragomirov found this attribute more inherent in Russian soldiers than their Western counterparts, due to the latter's reliance on "modern fire weapons" as well as their "weak and decadent [condition] because of modern life" - this, despite the drubbing the latter had accorded his charges a mere two years before he penned his paean (Plamper 270). This moral transformation travels well, at any rate, and may, with time and training (be it "on-the-job," as in Henry's case, or the now-standard "basic" variety) occur in any 
trench; it even transfers across the Atlantic, judging from descriptions, toward the end of The Red Badge, of Henry and his comrades

pitching forward insanely ... moblike and barbaric, but tuned in strange keys that can arouse the dullard and the stoic. [This] mad enthusiasm ... seemed ... incapable of checking itself before granite and brass. There was the delirium that encounters despair and death, and is heedless and blind to the odds. It is a temporary but sublime absence of selfishness (125-6).

Oddly, this very abandonment of self and all sense of self-preservation is precisely "the reason ... the youth wondered, afterward, what reasons he could have for being there" (126). The passage, again, recalls Petsh's hallucinatory consciousness in the hand-to-hand combat in which he bayonets a Frenchman. Reverting, again, to Gierigk, we see, in both instances, "exactly that which Nietzsche called the 'aesthetic condition the ecstatic abandonment to recklessness, heedless of all danger'” (243). This "berserkdom" soon succumbs to another damper to fear - combat fatigue, which lends "the youth ... a vague belief that he had run miles ... [and] was now in some new and unknown land" (126). The regiment, at large, suffers another symptom of the moral torpor caused by war, as it inures itself to increasing losses among the ranks upon see[ing]some of their comrades dropping with moans and shrieks. A few lay under foot, still or wailing, and now, for an instant, the men stood, their rifles slack in their hands, and watched the regiment dwindle. The spectacle seemed to paralyze them, overcome them with a fatal fascination. They stared woodenly at the sights, and, lowering their eyes, looked from face to face. It was a strange pause, and a strange silence. (126) 
Only when the lieutenant challenges Henry to "Come on! Come on" does the youth join the officer and Wilson in leading "the scurrying mass" of the regiment across a pasture. At this juncture, there occurs one of the most curious references in the book, as Henry, running his hardest to cross the field without getting shot "duck[s] his head low, like a football player" (129). This anachronism owes, perhaps, to the game's inherent combativeness serving as one of the early influences on Crane's war writing. A college sport at its inception, football debuted in late 1869, nearly five years after the Civil War ended and seven years after the battle Foote insists was the prototype for Crane's novel. The reference, nonetheless, flows nicely into another American pastime, as Henry suddenly finds purpose in his presence amid the chaos and carnage through a nascent devotion to the symbol around which he and his comrades rally. As he runs, head down, toward the foe, he feels "[w]ithin him ...born a love, a despairing fondness for this flag which was near him.... He kept near, as if it could be a saver of lives, and an imploring cry went from his mind" (129). One life the banner can't save, however, is that of its bearer, who is shot "as if struck by a bludgeon" yet keeps grasping the standard into the afterlife, as the two friends struggle to wrest it from his grasp (129). As their fellows retreat, there ensues between Henry and Wilson "a small scuffle over the flag. . . Each felt satisfied with the other's possession of it, but each felt bound to declare, by an offer to carry the emblem, his willingness to further risk himself (130). As Robertson notes in a chapter that carries his sole reference to Crane's novel:

Those standards were the most visible signs of patriotism. They signified the devotion of men to their unit, state, country and cause. The most consistent record of heroism during the war came from the men who bore the flag. It was the 
symbol around which soldiers rallied in the heat of battle. To keep the flag flying was their all-consuming objective.

Enemy soldiers delivered their deadliest fire at those holding aloft the colors. Capturing a battle flag was one of the war's outstanding feats. Losing one's banner to the enemy was a shame second only to cowardice. Troops took to heart a saying often repeated: "The post of danger is the post of honor" (136).

Henry eventually gains the upper hand. As enemy soldiers pour out of the woods at the start of Chapter XXII, he watches them "dodge and duck at the long screeching of shells ...thrown in giant handfuls over them" (142). His new-found confidence enables him to stand his ground and smile while watching them scurry, as had Volodya observing his own charges scaling the Malakov Redoubt. The entire 304th has shed all apprehension and given itself entirely over to battle. Henry grows unconscious of not just the oaths he casts at the enemy and his own breathing, but also the flag's being in his charge. Spotting a line of enemy soldiers within perilous range, the men, now instilled with soldierly instinct, "immediately let drive their flock of bullets without waiting for word or command" (145). Personifying their determination, Henry resolves "not to budge whatever should happen" (146). Nor will he forgive the officer who had berated the regiment. Redressing his insults - be they "mule drivers" or "mud diggers" - has become Henry's objective; in fact, the youth's contempt for the speaker outstrips that he feels for the foe, and Henry, now as prone to valor as once he had been to fear, decides his dead body should serve as "a great and salt reproach" (146). The salt at issue is, presumably, the kind you'd rub into the wounded conscience an officer worth his salt should suffer after belittling foot soldiers engaged in the heavy lifting of a noble cause, then learning 
how selflessly they had offered that "last full measure of devotion" Lincoln would eulogize less than a year after the battle on which the novel is based. A healthy dose of pepper would nicely enhance such a reproach.

This impression increases throughout the ten-page coda, in which we note how the regiment has matured into a well-oiled fighting machine, with Henry's perceptions as flag holder, keeping "the bright colors to the front," prompting his fellows' responses to enemy movements. As standard bearer, lacking a rifle, Henry now proves utterly defenseless against an "inscrutable" enemy menace from which only the bravery, fidelity and marksmanship of his confreres can save him. Evidence of this attitude marks a dramatic change in the protagonist and an affirmation of the spirit of unity - and Union that The Red Badge has celebrated for more than a century.

In a happy ending, a Hollywood ending - simple but satisfying in showing a complete reversal (much for the better) of the protagonist's fate - Henry, after the battle, lies resting in a shock of tall grass, a nearby railing keeping the regimental flag aloft, as "[h]is friend, jubilant and glorified, holding his treasure with vanity, came to him there. They sat side by side and congratulated each other.” (153). This sanguine scene could not contrast more starkly with the sanguinary ones in which the Kozeltsov brothers die, nor with the final image of the Russian defenders of Sevastopol, after retreating across the Roadstead and turning to see a French flag fluttering atop the Malakhov Redoubt:

"Almost every soldier looking back at the abandoned town from the North Side, sighed with inexpressible bitterness in his heart and made a menacing gesture towards the enemy" (Tolstoy 204). This contrast looms larger when viewed in light of the side each pair fought for in its respective conflict - the victors in the former case, the vanquished in 
the latter. It grows exponentially when viewed in relation to the cause giving rise to each war, and the relation the pair's respective side had to that cause: in the former case, preserving a Union dedicated to the proposition that all men are created equal, and, in the latter, a land grab clad in holy garb. Such considerations, pertaining to what Gierick calls "the condition of war," could barely be more alien to artworks that portray the perceptions of individuals caught up in deadly conflict, or what Gierick calls "the act of war." This contrast contributes to our appreciation of the works' most intimate tie - an urgency to dig in the trenches of the imperiled human psyche. The Red Badge closes in the same tenor in which the Sevastopol Sketches open, and, after sloughing through a young man's succumbing to, then struggling to confront and conquer, fear, readers should find no more fitting final benediction to the tale of Henry Fleming's (and Wilson's) transformation than Tolstoy's tribute to Sevastopol's defenders: "You will clearly recognize in the men you have just seen those heroes who gladly prepared for death and whose spirits did not flag during those dismal days but rose" (96). 


\section{References cited}

Bartlett, Rosamund. Tolstoy: A Russian Life. Boston, Mass. Houghton Mifflin Harcourt, 2011.

Cady, Edwin H. Poems and Poets: Stephen Crane. Poetry Foundation. 17 Feb 2017. https://www.poetryfoundation.org/poems-and-poets/poets/detail/stephen-crane

Chernyshevsky, N.G. "Chernyshevsky on Tolstoy." Tolstoi: The Critical Heritage. Ed. A.V. Knowles. London: Routledge \& Kegan Paul, 1978.

Civil War Trust. “Oliver O. Howard.” 19 May 2016. http://www.civilwar.org/education/ history/biographies/oliver-howard.html?referrer=https://www.google.com/\#.

Cox, James M. “On Stephen Crane's The Red Badge of Courage." The Red Badge of Courage: a Norton Critical Edition. Ed. Donald Pizer and Eric Carl Link. New York: W.W. Norton \& Co., 2008.

Crane, Stephen. The Red Badge of Courage. New York: Penguin, 1994.

---. Wounds in the Rain: War Stories. Plainview, N.Y.: Books for Libraries Press, 1900/1976.

cummings, e.e. "as freedom is a breakfast food." Complete Poems. New York: Liveright Publishing Corp., 1926/1991.

Dickey, James. Introduction. The Red Badge of Courage. By Stephen Crane. New York: Penguin. 1997. vii-xii.

Eikhenbaum, Boris. The Young Tolstoi. Trans.\& ed. Gary Kern. Ann Arbor: Ardis, 1972.

Figes, Orlando. The Crimean War: A History. New York: Metropolitan Books, 2010.

Foote, Shelby. Introduction. The Red Badge of Courage. By Stephen Crane. New York: The Modern Library, 1993.

Ford, Ford Maddox. The Red Badge of Courage. By Stephen Crane. New York: The Modern Library, 1993.

Gerigk, Horst-Jürgen. Die Russen in Amerika: Dostojewskij, Tolstoj, Turgenjew, und Tschechow in ihrer Bedeutung für die Literatur der USA. [The Russians in America: Dostoevsky, Tolstoy, Turgenev, and Chekhov and Their Meaning for the Literature of the United States.] Hürtgenwald, Germany: Guido Pressler Verlag, 1995. 
Greenwood, E. B. Tolstoy: The Comprehensive Vision. New York: St. Martin's Press, 1975.

Gullason, Thomas A. "New Sources for Stephen Crane's War Motif." ML Notes, pp.572-5, Vol. 72, No. 8, 1957.

Hardy, Thomas. "The Man He Killed." Poetry Foundation, 7 Jan. 2016. www.poetryfoundation.org/ poems-and-poets/poems/details/44329.

Hemingway, Ernest. A Farewell to Arms. New York: Scribners, 1929/2003.

Hilliard, John Northern. "Stephen Crane: Letters to a Friend About His Ambition, His Art and His Views on Life." Stephen Crane. Edited by Harold Bloom. New York: Infobase Publishing, 2009.

Holton, Milne, Cylinder of Vision: The Fiction and Journalistic Writing of Stephen Crane, Louisiana State University Press, 1972.

Hosking, Geoffrey A. Russia and the Russians: A History. Cambridge, Mass.: Belknap Press of Harvard University Press. 2001.

LaRocca, Charles J. "The Historical Setting of The Red Badge of Courage." The Red Badge of Courage: a Norton Critical Edition. Ed. Donald Pizer and Eric Carl Link. New York: W.W. Norton \& Co., 2008.

Levenson, J.C. Introduction, The Red Badge of Courage. Charlottesville: UP of Virginia. 1975.

Lincoln, Abraham. The Gettysburg Address. Lincoln Memorial.

Mitgang, Herbert. ''Badge of Courage': Stephen Crane, Making Real a War He Never Fought." Books of the Times. The New York Times. August 18, 1998.

Mitchell, Reid. The Vacant Chair: The Northern Soldier Leaves Home. Oxford, England. Oxford UP, 1993.

Nagel, James. "Impressionism in The Red Badge of Courage." The Red Badge of Courage/Stephen Crane: A Norton Critical Edition, $4^{\text {th }}$ Edition. Ed. Donald Pizer and Eric Carl Link. New York: W.W. Norton \& Co, 2008.

Plamper, Jan. "Fear: Soldiers and Emotion in Early Twentieth-Century Russian Military Psychology," Slavic Review, vol. 68, no. 2, Summer 2009, pp. 259-83. research.gold.ac.uk/10132/1/SR-Summer-2009_complete\%20issue.pdf 
Plokhy, Serhii. "The City of Glory: Sevastopol in Russian Historical Mythology." Journal of Contemporary History, Vol. 35, No. 3 (July 2000), pp. 369-383. 8 Mar. 2015. www.jstor.org/ stable/261026.

Robertson, James. The Untold Civil War: Exploring the Human Side of War. ed. Neil Kagan. Washington, D.C.: National Geographic. 2014.

Simmons, Ernest Joseph. Introduction to Tolstoy's Writings. 1968. 13 Feb 2016. https://www.ourcivilisation.com/smartboard/shop/smmnsej/tolstoy/chap2.htm

Solomon, Eric. "Stephan Crane's War Stories." Texas Studies in Literature and Language. vol.3, no. 1. (Spring 1961) pp.67-80. 21 April 2017 http:// www.jstor.org/stable/40753709.

Sorrentino, Paul. A Life of Fire. Cambridge, Mass.: Harvard UP, 2014.

Starrett, Vincent. Introduction. Men, Women and Boats. By Stephen Crane. Plainview, N.Y.: Books for Libraries Press, 1921/1970.

Stendhal. The Charterhouse of Parma. Trans. Richard Howard. New York: The Modern Library,1999.

Tenneyson, Alfred, Lord. "The Charge of the Light Brigade." National Center. 19 April 2016. http://www.nationalcenter.org/ChargeoftheLightBrigade.html

Tolstoy, Alexandra. Tolstoy: A Life of My Father. Trans. By Elizabeth Reynolds Hapgood. New York: Octagon Books, 1973.

Tolstoy, Leo. "Sevastopol." Collected Shorter Fiction. Vol. 1. Trans. Louise and Aylmer Maude and Nigel J. Cooper. New York: Knopf, 2001.

Unsigned Review, Fatherland Notes, No. 11. 1856. Tolstoy: The Critical Heritage. London: Routledge \& Kegan Paul, 1978.

Wilson, A.N. Tolstoy. New York: W.W. Norton \& Company Inc., 1988.

Wood, Paul. "The Unbroken Chain: Tolstoy's legacy of nonviolence influenced many great leaders." College of Liberal Arts \& Sciences. University of Illinois at Urbana-Champaign. 2009. 6 Dec. 2015. www.las.illinois.edu/alumni/magazine/ articles/2009/tolstoy. 